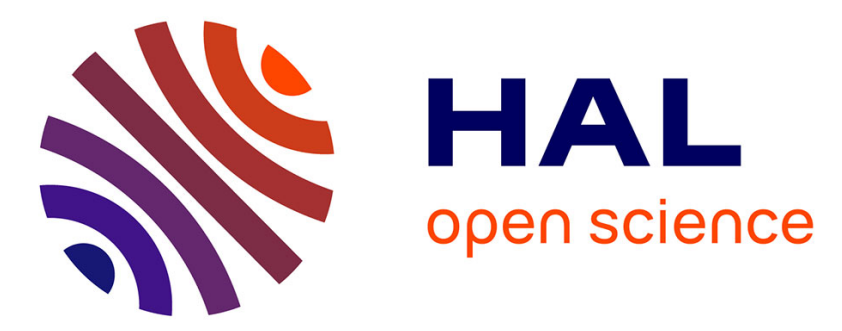

\title{
Experimental and numerical evaluation of the hygrothermal performance of a hemp lime concrete building: A long term case study
}

Bassam Moujalled, Yacine Ait Oumeziane, Sophie Moissette, Marjorie Bart, Christophe Lanos, Driss Samri

\section{To cite this version:}

Bassam Moujalled, Yacine Ait Oumeziane, Sophie Moissette, Marjorie Bart, Christophe Lanos, et al.. Experimental and numerical evaluation of the hygrothermal performance of a hemp lime concrete building: A long term case study. Building and Environment, 2018, 136, pp.11-27. 10.1016/j.buildenv.2018.03.025 . hal-01738378

\section{HAL Id: hal-01738378 \\ https://hal.science/hal-01738378}

Submitted on 12 Apr 2019

HAL is a multi-disciplinary open access archive for the deposit and dissemination of scientific research documents, whether they are published or not. The documents may come from teaching and research institutions in France or abroad, or from public or private research centers.
L'archive ouverte pluridisciplinaire HAL, est destinée au dépôt et à la diffusion de documents scientifiques de niveau recherche, publiés ou non, émanant des établissements d'enseignement et de recherche français ou étrangers, des laboratoires publics ou privés. 


\section{Experimental and numerical evaluation of the hygrothermal}

\section{performance of a hemp lime concrete building: a long term}

\section{case study}

Bassam Moujalled $^{\mathrm{a},{ }^{*}}$, Yacine Aït Ouméziane $^{\mathrm{b}}$, Sophie Moissette ${ }^{\mathrm{c}}$, Marjorie Bart ${ }^{\mathrm{c}}$, Christophe Lanos ${ }^{c}$, Driss Samrid

${ }^{a}$ CEREMA, Direction Centre-Est, 46 Rue St Théobald, F-38081 L'Isle d'Abeau, France

${ }^{\mathrm{b}}$ FEMTO-ST Institute, Univ. Bourgogne Franche-Comte, CNRS, 2 avenue Jean Moulin, 90000 Belfort, France

' LGCGM EA3913, University of Rennes 1, 3 rue du clos Courtel, 35704 RENNES, France ${ }^{d}$ CEREMA, Direction Sud-Ouest, Rue Pierre Ramond, F-33166 Saint-Médard-en-Jalles, France

"Corresponding author:

E-mail address: bassam.moujalled@cerema.fr

Tel: +33474275155 , Fax: +33474275252

\section{Abstract}

Hemp-lime concrete (HLC) is a bio-based material which is currently undergoing a growing development. HLC is a low embodied energy material and an excellent hygrothermal regulator. Its thermal, hygric and mechanical properties are well known, and its capacity to reduce energy needs and to improve hygrothermal comfort is demonstrated across many laboratory and numerical studies. However, there are few works about its hygrothermal performance in real climatic conditions on the scale of a building. In order to address this issue, a long term in-situ measurement is carried out to analyze the hygrothermal performance of a HLC individual dwelling-house during 4 years. The analysis of the hygrothermal behavior of a wall is achieved by comparing measurements and numerical simulations results. In this study, two simulation tools are used and compared. The first tool 
is based on the well-known Wufi software. In the second simulation tool, hysteresis phenomenon and temperature-dependence of moisture content are considered in a heat and moisture transfer model. In-situ monitoring of walls temperatures shows the ability of HLC to almost completely dampen variations of external temperature with about 12 hours time-shift. The evolution of indoor relative humidity confirms that HLC has an excellent moisture buffer performance. Comparisons between numerical and experimental results highlight the interest to consider the effect of temperature on sorption process in the simulation of the hygrothermal response of a HLC wall in real climatic conditions.

\section{Keywords:}

Hemp concrete, Building envelope, Hygrothermal behavior, In-situ measurement, heat and moisture transfer model

\section{Introduction}

In a context of sustainable development, one of the concerns in building construction is the choice of environmentally friendly materials. In fact, it has some impacts on exhaustion of natural resources, energy consumption and polluting emission. In this framework, bio-based materials appear as a good solution to address these issues [1-5]. This study deals with Hemp-Lime Concrete (HLC) made of hemp shiv (renewable raw and fast-growing bio-based material) and of lime which has a lower embodied energy than cement [6]. The use of hemp in construction was demonstrated to be a promising opportunity to radically decrease the carbon footprint of buildings [7]. Depending on its composition and manufacturing process of compaction, HLC can be used for several applications: wall, floor and roof. HLC is characterized by a very high porosity (more than $70 \%$ for a "wall' mixture") and a low dry density around $400 \mathrm{~kg} \cdot \mathrm{m}^{-3}$ for a "wall mixture" [4,5,8-12]. It shows low compressive strength and is consequently mainly used as filling material associated with a wooden frame $[4,13,14]$. However, HLC shows interesting hygrothermal properties for its use in buildings: a low thermal conductivity about $0.1 \mathrm{~W} \cdot \mathrm{m}^{-1} \cdot \mathrm{K}^{-1}$ and a high vapor permeability about $10^{-11}-10^{-10}$ $\mathrm{kg} \cdot \mathrm{m}^{-1} \cdot \mathrm{s}^{-1} \cdot \mathrm{Pa}^{-1}[8-11,14-17]$. A moisture buffer value (MBV) above $2 \mathrm{~g} \cdot \mathrm{m}^{-2} / \% \mathrm{RH}$ determined 
in accordance with the Nordtest protocol [18] qualifies HLC as an excellent moisture regulator $[5,12,19]$.

Moreover, HLC presents a significant hysteretic behavior that influences the evolution of the moisture content inside the material. Hysteresis is often not considered in sorption process modeling. The relation between moisture content and relative humidity is modelled by a single curve (usually the main adsorption curve). Due to the hysteretic effect, the equilibrium moisture content depends not only on relative humidity but also on moisture history. Adsorption and desorption cycles measured in [20] for HLC show the influence of hysteresis on the moisture content and hygric capacity evolutions. Temperature influences also the equilibrium moisture content: the warmer the temperature, the lower will be the equilibrium moisture content at the same relative humidity. Some measurements at $10^{\circ} \mathrm{C}$ and $23^{\circ} \mathrm{C}$ are provided for HLC in [21]. Hysteresis phenomenon and temperature effects on sorption process are most often neglected for modeling the moisture content evolution in heat and moisture transfer models. This can cause significant discrepancies to predict the hygrothermal response of a material subjected to climatic variations as shown by Zhang et al. in the case of wood materials [22].

The last researches on the transient hygrothermal response of HLC have been essentially led on the wall scale in laboratory conditions [23-26]. In particular, these studies show the relevance to consider hysteresis and hygric history to improve numerical results [25-27]. Nevertheless, there are few works about its hygrothermal performance in real climatic conditions. Bejat et al. in France [28] and Shea et al. in Great Britain [29] have led some experimental campaigns on hemp concrete wall subjected to real climatic conditions. The comparison between numerical and experimental results show the inability of commercial softwares to reproduce the effective hygrothermal response of the wall. More recently, Costantine et al. [5] have focused their study on the scale of a hemp-concrete building for a 10-month period under real weather conditions, but they are not interested in the effective hygrothermal behavior of HLC and temperature and relative humidity inside the wall were not monitored. 
In order to predict the real hygrothermal behavior of this material, this paper presents a field study of the hygrothermal response of a HLC building subjected to climatic variations, located in South West of France.

The main objective is to look for more realistic thermal and hygric behavior of hemp concrete under real climatic conditions. The originality of this paper lies in studying the hygrothermal response of a HLC individual dwelling-house in real climatic conditions, at both wall and building scales, for a long monitoring period covering four whole years. First, a global experimental analysis is performed to evaluate on the full scale the performance of the building. External weather conditions, indoor air temperature and relative humidity of several rooms are monitored to discuss the indoor comfort. Temperature and relative humidity of north-faced and west-faced walls are monitored at two different depths and at surfaces to analyze the hygrothermal behavior of walls. Then, the comparison between experimental and numerical results of instrumented walls are discussed considering the effect of temperature dependence and hysteresis on HLC sorption process.

\section{Experimental setup}

The monitored building is a 2-floor single-detached house of $250 \mathrm{~m}^{2}$ with a semi-basement. It is located close to Perigueux in South West of France at $180 \mathrm{~m}$ above sea level. The weather is mild and humid, typical of temperate and oceanic climates. The building is surrounded by vegetation that increases the humidity of the local environment.

The house was built in 2011 and is occupied by four inhabitants ( 2 adults and 2 children) since December 2011. The building design is based on bioclimatic architecture with large glazing area of $18 \mathrm{~m}^{2}$ on the south façade and prow roof overhang (Fig. 1) in order to maximize the solar gain during winter while avoiding summer overheating. Its envelope is made of $30 \mathrm{~cm}$ thick HLC sprayed into walls of a timber frame structure. HLC is also used in roof and intermediate floor in $10 \mathrm{~cm}$ and $15 \mathrm{~cm}$ thickness respectively. The walls are internally and externally protected with lime-sand plasters, except the internal face of the walls in the office room. The HLC was sprayed during April-May 2011, and the plasters were 


\section{ACCEPTED MANUSCRIPT}

applied immediately after finishing the walls construction. A wood pellet boiler coupled with $12.6 \mathrm{~m}^{2}$ of solar collectors provides energy for heating and domestic hot water. Heat is distributed in the house through radiant floor at the ground level and radiant walls at the top level. A balanced ventilation system with heat recovery is used for ventilation.

Fig. 2 presents the ground and floor plans of the building. The main living room and the master bedroom are located on the ground floor, while the other bedrooms are located on the floor level.

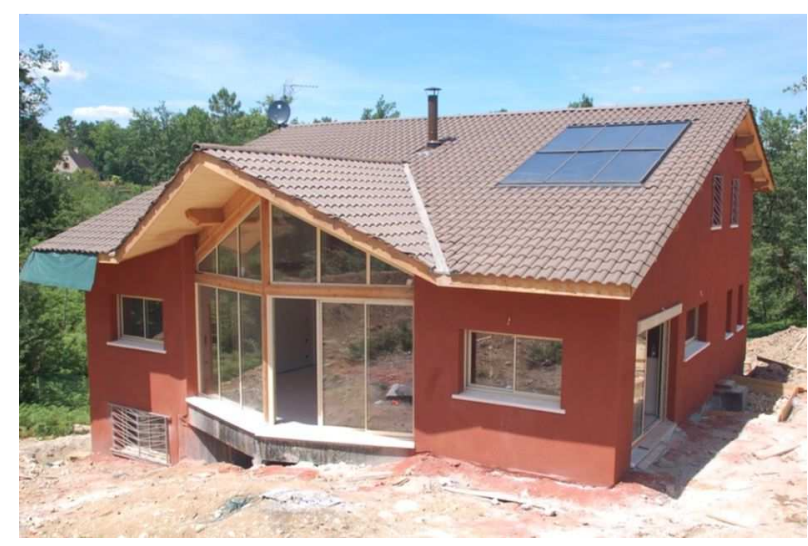

Fig. 1. View of the south facade of the building.
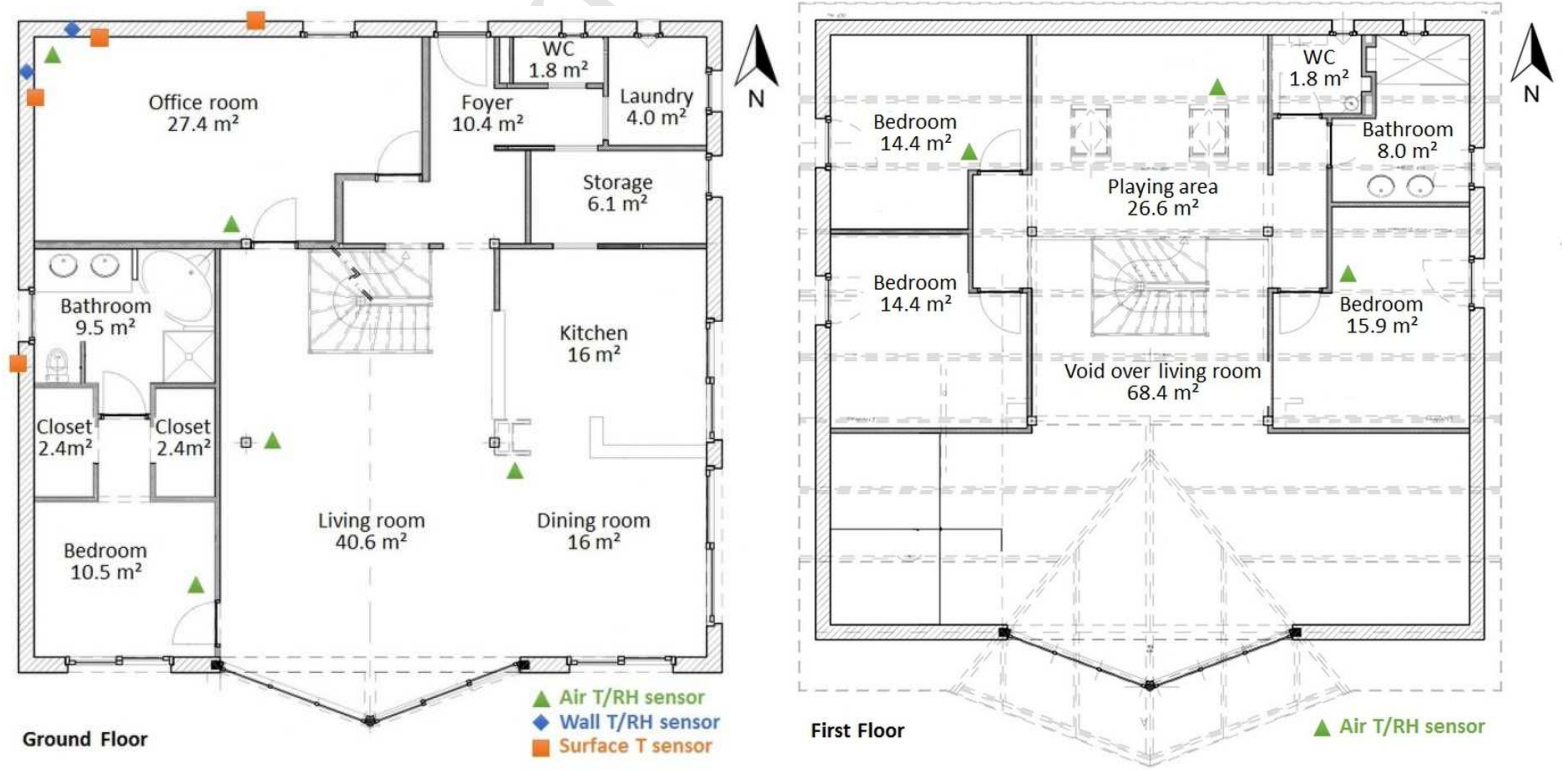

Fig. 2. Floor plans of the building with the location of sensors. 
Thermographic inspection and airtightness test were carried out in order to evaluate the building envelope performance. The thermographic inspection helps to detect insulation defects, especially thermal bridges that may occur due to the timber frame structure. The blower door test helps to evaluate the level of air permeability according to the standard NF EN 13829 [30] and to detect the air leakages through the envelope. The thermographic diagnostic is performed using the FLIR® Thermacam E4 infrared camera, and the airtightness testing with the blower door Minneapolis® system.

The hygrothermal performance of the indoor environment was monitored using 8 Hobo data loggers (HOBO U12-002) that measured the indoor air temperature and relative humidity in different rooms of the house. Special care was taken to prevent the probe from being subjected to radiation from neighboring heat sources. Fig. 2 shows the locations of the sensors in the different rooms.

In order to evaluate the hygrothermal performance of the envelope, temperature and relative humidity monitoring was done for the west and north-facing walls of the office room. The north-facing wall is sunless; it was monitored for comparison purposes with the west-facing wall. Both walls are made of $30 \mathrm{~cm}$ of HLC, and $3 \mathrm{~cm}$ of exterior lime-sand plaster. They were initially uncoated at the interior surface. A textile inner lining was added few months after the beginning the monitoring for aesthetic reason, but its hygrothermal resistance is neglected in this study. Each wall is monitored as shown in Fig. 3.

Two sensors are placed within the wall and measure temperature and relative humidity at two different depths (15 and $25 \mathrm{~cm}$ from the interior surface). The sensors are $12 \mathrm{~mm}$ diameter. They were inserted into the wall through drilled holes at the specified depths. Once the sensors placed, holes were sealed with acrylic sealant. This measurement technique is validated in [10]. Two thermocouples (STCS from Prosensor), fixed with adhesive tape, measure the interior and exterior wall surface temperatures. The indoor air temperature and relative humidity of the studied room are measured with two Hobo data loggers located near the walls and at the center of the room. Outdoor air temperature and relative humidity are 
measured using a Hobo datalogger that is placed on the north facade (HOBO U23-001 from Onset). Besides, a complete weather station (HOBO U30 from Onset) was added lately in December 2014 close to the house. It measures outdoor air temperature and relative humidity, horizontal solar radiation, wind speed and direction, and rainfall.

All data were monitored continuously from February 2012 till January 2016 during 4 years with a time step of 15 minutes. Table 1 presents the measurement parameters, the devices and their specifications. These devices are all new devices whose calibration has been certified by the manufacturer.
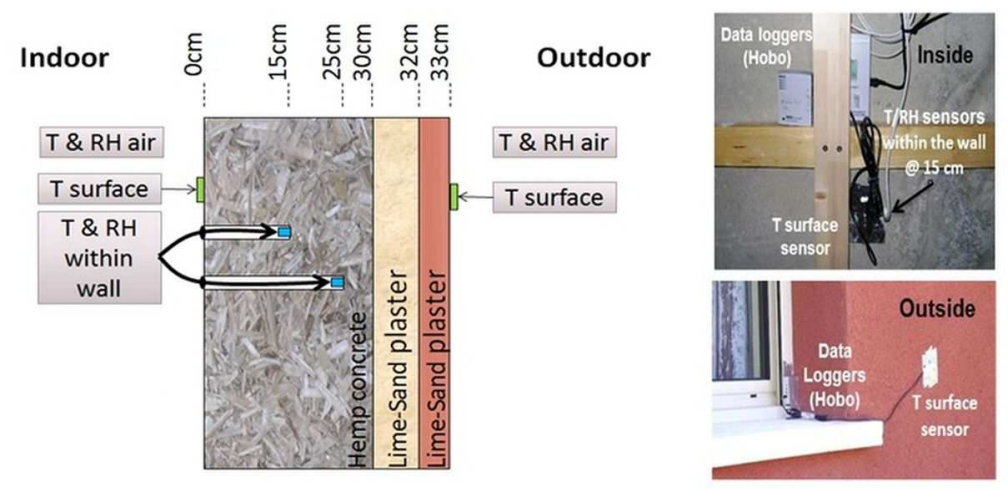

\begin{tabular}{|c|c|c|c|c|c|}
\hline $\begin{array}{l}\text { Measurement } \\
\text { parameter }\end{array}$ & $\begin{array}{l}\text { Data logger } \\
\text { reference }\end{array}$ & $\begin{array}{l}\text { Sensor } \\
\text { reference }\end{array}$ & $\begin{array}{l}\text { Measurement } \\
\text { range }\end{array}$ & Accuracy & Drift \\
\hline \multirow{2}{*}{$\begin{array}{l}\text { Indoor air } \\
\text { T \& RH }\end{array}$} & \multirow{2}{*}{$\begin{array}{l}\text { HOBO U12- } \\
012 \\
@ 15 \text { min }\end{array}$} & \multirow{2}{*}{ HOBO U12-012 } & $\mathrm{T}:-20^{\circ}$ to $70^{\circ} \mathrm{C}$ & $\mathrm{T}: \pm 0.35^{\circ} \mathrm{C}$ & $\mathrm{T}: 0.1^{\circ} \mathrm{C} / \mathrm{yr}$ \\
\hline & & & $\mathrm{RH}: 5 \%$ to $95 \%$ & $\begin{array}{l}\mathrm{RH}<90 \%: \pm 2.5 \% \\
\mathrm{RH}>90 \%: \pm 5 \%\end{array}$ & $\mathrm{RH}:<1 \% / \mathrm{yr}$ \\
\hline Surface T & $\begin{array}{l}\text { HOBO U12- } \\
006 \\
@ 15 \text { min }\end{array}$ & STCS & $\mathrm{T}:-20^{\circ}$ to $70^{\circ} \mathrm{C}$ & $\mathrm{T}: \pm 0.35^{\circ} \mathrm{C}$ & $\mathrm{T}:<0.1^{\circ} \mathrm{C} / \mathrm{yr}$ \\
\hline \multirow[t]{2}{*}{ Wall T \& RH } & \multirow{2}{*}{$\begin{array}{l}\text { HOBO U14- } \\
002 \\
@ 15 \text { min }\end{array}$} & \multirow[t]{2}{*}{ S-THB-M002 } & $\mathrm{T}:-40^{\circ}$ to $75^{\circ} \mathrm{C}$ & $\mathrm{T}: \pm 0.21^{\circ} \mathrm{C}$ & $\mathrm{T}:<0.1^{\circ} \mathrm{C} / \mathrm{yr}$ \\
\hline & & & $\mathrm{RH}: 0 \%$ to $100 \%$ & $\begin{array}{l}\mathrm{RH}<90 \%: \pm 2.5 \% \\
\mathrm{RH}>90 \%: \pm 5 \%\end{array}$ & $\mathrm{RH}:<1 \% / \mathrm{yr}$ \\
\hline \multirow{2}{*}{$\begin{array}{l}\text { Outdoor air } \\
\text { T \& RH }\end{array}$} & \multirow{2}{*}{$\begin{array}{l}\text { HOBO U23- } \\
001 \\
@ 15 \text { min }\end{array}$} & \multirow[t]{2}{*}{ HOBO U23-001 } & $\mathrm{T}:-40^{\circ}$ to $70^{\circ} \mathrm{C}$ & $\mathrm{T}: \pm 0.21^{\circ} \mathrm{C}$ & $\mathrm{T}:<0.1^{\circ} \mathrm{C} / \mathrm{yr}$ \\
\hline & & & $\mathrm{RH}: 0 \%$ to $100 \%$ & $\begin{array}{l}\mathrm{RH}<90 \%: \pm 2.5 \% \\
\mathrm{RH}>90 \%: \pm 5 \%\end{array}$ & $\mathrm{RH}:<1 \% / \mathrm{yr}$ \\
\hline \multirow{5}{*}{$\begin{array}{l}\text { Weather station } \\
\text { (only during } \\
\text { the last year) }\end{array}$} & \multirow{5}{*}{$\begin{array}{l}\text { HOBO U30 } \\
\text { @ } 15 \text { min }\end{array}$} & \multirow{2}{*}{$\begin{array}{l}\text { T\&RH: } \\
\text { S-THB-M002 }\end{array}$} & $\mathrm{T}:-40^{\circ}$ to $75^{\circ} \mathrm{C}$ & $\mathrm{T}: \pm 0.21^{\circ} \mathrm{C}$ & $\mathrm{T}:<0.1^{\circ} \mathrm{C} / \mathrm{yr}$ \\
\hline & & & $\mathrm{RH}: 0 \%$ to $100 \%$ & $\begin{array}{l}\mathrm{RH}<90 \%: \pm 2.5 \% \\
\mathrm{RH}>90 \%: \pm 5 \%\end{array}$ & $\mathrm{RH}:<1 \% / \mathrm{yr}$ \\
\hline & & $\begin{array}{l}\text { Solar radiation: } \\
\text { S-LIB-M003 }\end{array}$ & $0-1280 \mathrm{~W} / \mathrm{m}^{2}$ & $\pm 10 \mathrm{~W} / \mathrm{m}^{2}$ or $\pm 5 \%$ & $< \pm 2 \% / y r$ \\
\hline & & $\begin{array}{l}\text { Wind speed: } \\
\text { S-WSA-M003 }\end{array}$ & 0 to $45 \mathrm{~m} / \mathrm{s}$ & $\pm 1.1 \mathrm{~m} / \mathrm{s}$ & - \\
\hline & & $\begin{array}{l}\text { Wind direction: } \\
\text { S-WDA-M003 }\end{array}$ & 0 to $355^{\circ}$ & $\pm 5^{\circ}$ & - \\
\hline
\end{tabular}

Fig. 3. Sensors location through the wall and on the internal and external surfaces. 


\section{ACCEPTED MANUSCRIPT}

Table 1. Specifications of the measurement devices.

\section{Model}

\subsection{Heat and moisture transfer model}

The hygrothermal performance of the monitored north HLC wall located in the office room is simulated with two different simulation tools.

The first simulation tool used in this paper is WUFI Pro $5.1{ }^{\circledR}$ software [31]. This version of WUFI is able to simulate one-dimensional heat and moisture transfer in porous materials.

The second simulation tool uses the Matlab software. The developed model is fully described in [32] and main points are reported in [21]. Only a short summary is presented in this paper. According to Künzel formalism [31], the driving potentials of the 1D hygrothermal model can be expressed in terms of two potentials: temperature $T$ and relative humidity $\varphi$. The governing system of equations of moisture and heat transfer is given in Eq. (1) and (2):

$$
\begin{gathered}
\xi_{\varphi} \frac{\partial \varphi}{\partial t}+\xi_{T} \frac{\partial T}{\partial t}=\nabla\left[\left[\delta_{p} \nabla\left(\varphi p_{s a t}\right)\right]\right]+\nabla\left[D_{l} \nabla \varphi\right] \\
{\left[\rho_{0} c_{0}+c_{l}\left(w+\left(T-T_{r e f}\right) \xi_{T}\right)\right] \frac{\partial T}{\partial t}+\left[c_{l}\left(\left(T-T_{r e f}\right) \xi_{\varphi}\right)\right] \frac{\partial \varphi}{\partial t}} \\
=\nabla\left[\lambda \nabla T+\left(l_{v}+c_{v}\left(T-T_{r e f}\right)\right)\left[\delta_{p} \nabla\left(\varphi p_{s a t}\right)\right]\right]+\nabla\left[c_{l}\left(T-T_{r e f}\right)\left[D_{l} \nabla \varphi\right]\right]
\end{gathered}
$$

$\delta_{p}\left[\mathrm{~kg} \cdot \mathrm{m}^{-1} \cdot \mathrm{s}^{-1} \cdot \mathrm{Pa}^{-1}\right]$ is the vapor permeability, $D_{I}\left[\mathrm{~kg} \cdot \mathrm{m}^{-1} \cdot \mathrm{s}^{-1}\right]$ the liquid conduction coefficient, $p_{\text {sat }}[\mathrm{Pa}]$ the saturated vapor pressure and $T_{\text {ref }}[\mathrm{K}]$ the reference temperature (equal to 296.15K). $c_{V}\left[\mathrm{~J} \cdot \mathrm{kg}^{-1} \cdot \mathrm{K}^{-1}\right]$ and $c_{l}\left[\mathrm{~J} \cdot \mathrm{kg}^{-1} \cdot \mathrm{K}^{-1}\right]$ are the specific heat capacity of, respectively, vapor and liquid water. $c_{0}\left[\mathrm{~J} \cdot \mathrm{kg}^{-1} \cdot \mathrm{K}^{-1}\right]$ is the specific heat capacity of the dry material. $\lambda\left[\mathrm{W} \cdot \mathrm{m}^{-1} \cdot \mathrm{K}^{-1}\right]$ is the thermal conductivity of the moist material and $I_{V}$ the latent heat of evaporation $\left[2.45 \times 10^{6}\right.$ $\mathrm{J} . \mathrm{kg}^{-1}$ at the temperature of $\left.296.15 \mathrm{~K}\right]$.

In these equations, $\xi\left[\mathrm{kg} \cdot \mathrm{m}^{-3}\right]$ is the hygric capacity with $u\left[\mathrm{~kg} \cdot \mathrm{kg}^{-1}\right]$ the moisture content and $\rho_{o}\left[\mathrm{~kg} \cdot \mathrm{m}^{-3}\right]$ the density of the dry material.

$$
\begin{aligned}
& \xi_{\varphi}=\left.\rho_{0} \frac{d u}{d \varphi}\right|_{T} \\
& \xi_{T}=\left.\rho_{0} \frac{d u}{d T}\right|_{\varphi}
\end{aligned}
$$


Neumann boundary conditions are chosen to model the exchange between the HLC wall and the indoor and outdoor environments.

Moisture exchange coefficient is deduced from the heat transfer coefficient with the Lewis relation [33]. The governing system of strongly coupled unsteady differential equations is implemented in Matlab with a finite differences method. The model was benchmarked against the international benchmark HAMSTAD WP2 [34]. The model was validated in [32] against all the test cases of the benchmark.

\subsection{Material properties modeling}

The properties of the HLC wall provided by the manufacturer gives a dry bulk density $\rho_{0}=$ $450 \mathrm{~kg} \cdot \mathrm{m}^{-3}$ and a dry heat conductivity $\lambda_{0}=0.11 \mathrm{~W} \cdot \mathrm{m}^{-1} \cdot \mathrm{K}^{-1}$. The hemp concrete hygrothermal properties used in this study are those experimentally determined in [11,12], which gives similar values.

In Wufi, logarithmic interpolations between the experimental data allow to determine the value of a parameter.

In the Matlab program, the hygrothermal properties of HLC are modeled in [21] from the experimental results obtained in [11,12]. These properties are listed in Table 2.

The main adsorption and desorption curves are built using the Van Genuchten model [35].

$$
u_{j}(\varphi)=u_{s a t}\left[\left(1+\left|\alpha_{j} \frac{R T}{M_{l} g} \ln (\varphi)\right|^{\eta_{j}}\right)^{-\left(1-\frac{1}{\eta_{j}}\right)}\right], j=\text { ads or des }
$$

where $u_{a d s}$ and $u_{\text {des }}$ respectively represent the main adsorption and desorption functions. $u_{\text {sat }}$ $\left[\mathrm{kg} \cdot \mathrm{kg}^{-1}\right]$ is the saturated moisture content. $R\left[8.314 \mathrm{~J} \cdot \mathrm{mol}^{-1} \cdot \mathrm{K}^{-1}\right]$ is the ideal gas constant, $M_{I}$ [18 g.mol $\left.{ }^{-1}\right]$ the molar water mass, $g\left[9.81 \mathrm{~m}^{2} \cdot \mathrm{s}^{-1}\right]$ the gravity acceleration and $T[296.15 \mathrm{~K}]$ the reference temperature.

The values of the parameters are given in Table 3. 


\section{Property}

Dry density $\rho_{0}$

Open porosity $n_{0}$

Vapor permeability $\delta_{p}$

Vapor diffusion resistance factor $\mu_{0}$

Liquid diffusion coefficient $D_{\text {l }}$

Fictitious vapor diffusion resistance

factor $\mu^{*}$

Critical moisture content $u_{c r}$

Equivalent thermal conductivity $\lambda$

Dry thermal conductivity $\lambda_{0}$

Saturated thermal conductivity $\lambda_{\mathrm{s}}$

Equivalent specific heat capacity $c^{*}$

Dry specific heat capacity $\mathrm{c}_{0}$

Vapor permeability of air $\delta_{p, a}$

\section{Expressions}

$450 \mathrm{~kg} \cdot \mathrm{m}^{-3}$

$68 \%$

$5 \cdot 10^{-11} \mathrm{~kg} \cdot \mathrm{m}^{-1} \cdot \mathrm{s}^{-1} \cdot \mathrm{Pa} \mathrm{a}^{-1}$

$$
\mu_{0}=\delta_{p, a} / \delta_{p}
$$

$$
D_{l}=\left(1 / \mu^{*}(u)-1 / \mu_{0}\right) \delta_{p, a} p_{s a t}
$$

$$
\mu^{*}(u)=\delta_{p, a}\left(23^{\circ} \mathrm{C}\right) / 4.0664 .10^{-11} \exp (20.814 . u)
$$

$$
\begin{gathered}
\mu^{*}\left(u_{c r}\right)=\mu_{0} \\
\lambda=\lambda_{s}+\left(\lambda_{0}-\lambda_{s}\right)\left(u_{s a t}-u\right) / u_{s a t} \\
\lambda_{0}=0.117 \mathrm{~W} \cdot \mathrm{m}^{-1} \cdot \mathrm{K}^{-1} \\
\lambda_{s}=0.6 \mathrm{~W} \cdot \mathrm{m}^{-1} \cdot \mathrm{K}^{-1} \\
c^{*}=c_{0}+u c_{l} \\
\mathrm{c}_{0}=1250 \mathrm{~J} \cdot \mathrm{kg}^{-1} \cdot \mathrm{K}^{-1} \\
\delta_{p, a}=2.31 .10^{-5} M_{l} / R T(T / 273.15)^{1,81}
\end{gathered}
$$

Table 2. Hygrothermal properties of HLC [21].

\begin{tabular}{lll}
\hline Parameter & Unity & Value \\
\hline $\mathrm{u}_{\text {sat }}$ & $\mathrm{kg} / \mathrm{kg}$ & 1.500 \\
\hline Adsorption & - & \\
$\mathrm{a}_{\text {ads }}$ & - & 0.0119 \\
$\eta_{\text {ads }}$ & & 2.0462 \\
\hline Desorption & - & \\
$\alpha_{\text {des }}$ & - & 0.0185 \\
$\eta_{\text {des }}$ & & 1.647 \\
\hline
\end{tabular}

Table 3. Hygrothermal properties of HLC. 
The properties of the render provided by the manufacturer gives a dry bulk density $\rho_{0}=935$ $\mathrm{kg} \cdot \mathrm{m}^{-3}$ and a dry heat conductivity $\lambda_{0}=0.19 \mathrm{~W} \cdot \mathrm{m}^{-1} \cdot \mathrm{K}^{-1}$.

The hygrothermal properties of the render selected for this study are given in WUFI database and reported in [36]. The main properties are summarized in Table 4.

\begin{tabular}{lc}
\hline Property & Expressions \\
\hline Dry density $\rho_{0}$ & $988 \mathrm{~kg} \cdot \mathrm{m}^{-3}$ \\
Total porosity $n_{0}$ & $58 \%$ \\
Vapor diffusion resistance factor $\mu_{0}$ & $\mu_{0}=24$ \\
Dry thermal conductivity $\lambda_{0}$ & $\lambda_{0}=0.165 \mathrm{~W} \cdot \mathrm{m}^{-1} \cdot \mathrm{K}^{-1}$ \\
Dry specific heat capacity $c_{0}$ & $c_{0}=850 \mathrm{~J} \cdot \mathrm{kg}^{-1} \cdot \mathrm{K}^{-1}$ \\
\hline
\end{tabular}

Table 4. Main hygrothermal properties of the render.

\subsection{Hysteresis model}

In comparison with Wufi, Matlab gives more computational scopes to the users. In particular, advanced hysteresis models can be implemented. In this paper, Huang's hysteresis model is chosen [37]. This model gives the more consistent results in comparison with other hysteresis models [20] for the studied hemp concrete.

Eq. (6) and (7) describe respectively the adsorption and desorption scanning curves after a series of alternating processes of desorption and adsorption:

$$
\begin{aligned}
& u(\varphi, i)=u_{r}(i)+\left(u_{s}(i)-u_{r}(i)\right) \frac{u_{a d s}(\varphi)}{u_{s a t}} \\
& u(\varphi, i)=u_{r}(i)+\left(u_{s}(i)-u_{r}(i)\right) \frac{u_{d e s}(\varphi)}{u_{s a t}}
\end{aligned}
$$

$u_{r}(i)$ and $u_{s}(i)$ respectively represent the residual and the saturated moisture contents. The index $i$ represents the number of switches between adsorption and desorption phases. The calculation of these parameters is based on the perfect closure of the scanning curve at reversal points. Scanning curve indexed $\mathrm{i}$ includes the last reversal point $\left(\varphi_{i}, u_{i}\right)$ and the penultimate reversal point $\left(\varphi_{i-1}, u_{i-1}\right)$. 


\subsection{Temperature-dependence of moisture content modeling}

The consideration of the effect of the temperature on moisture content relies on the thermodynamic evolution of the sorption mechanism [38]. This approach is based on the exothermic process of adsorption [39] and on the principle of Le Chatelier and the rule of Van't Hoff. As presented in [38], the Clausius-Clapeyron relation is used to express the heat

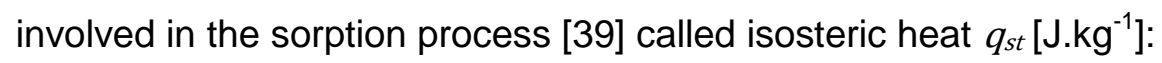

$$
q_{s t}(u)=-\left.\frac{R}{M_{l}}\left[\frac{\partial \ln \left(p_{v}\right)}{\partial\left(\frac{1}{T}\right)}\right]\right|_{u}
$$

$p_{V}[\mathrm{~Pa}]$ is the vapor pressure with $p_{\text {sat }}[\mathrm{Pa}]$ the saturated vapor pressure and $T[\mathrm{~K}]$ the temperature.

The isosteric heat $q_{s t}$ is determined from the experimental data of sorption isotherms obtained in [21] for hemp concrete at two temperatures: 10 and $23^{\circ} \mathrm{C}$. In this paper, the relation proposed by Powers and Brownyard [40] is implemented:

$$
q_{s t}(u)=l_{v}+\frac{a}{(b+u)^{c}}
$$

The parameters $a, b$ and $c$ are derived to fit the experimental data: $a=0.697 \mathrm{~J}^{\mathrm{kg}}{ }^{-1}, b=$ $0.0886 \mathrm{~kg} \cdot \mathrm{kg}^{-1}$ and $c=6.443$. Expressed under this form, the isosteric heat decreases with moisture content and asymptotically tends to the latent heat of vaporization.

The sorption isotherm at any temperature $T$ is deduced from the reference sorption isotherm $\varphi\left(T_{\text {ref }}, \mathrm{U}\right)$ as follows:

$$
\varphi(T, u)=\varphi\left(T_{r e f}, u\right) \frac{p_{s a t}\left(T_{r e f}\right)}{p_{s a t(T)}} e^{q_{s t}(u) \frac{M_{l}\left(T-T_{r e f}\right)}{R T T_{r e f}}}
$$

\section{Results and discussion}

\subsection{Experimental results}

4.1.1. Performance of the envelope and hygrothermal comfort analysis

The thermographic inspection was performed in March 2013 with covered sky, and adequate temperature differential of $15^{\circ} \mathrm{C}$ between the indoor and the outdoor. Fig. 4 shows the thermographic image of the exterior surfaces of the north/east corner of the house. The 
exterior surface temperature of the walls is clearly homogeneous. No structural thermal bridge due to the timber framework is observed. Also, no thermal losses are observed on the walls of the floor level due to radiant wall heating. Hence, the thermal insulation level of the HLC is good enough to prevent structural thermal bridges.

The airtightness test was carried out on the same day. The air permeability was calculated according to the French indicator $Q_{4 P a-S u r f}\left[\mathrm{~m}^{3} \cdot \mathrm{h}^{-1} \cdot \mathrm{m}^{-2}\right]$. It represents the ratio of the air leakage rate at $4 \mathrm{~Pa}$ over the envelope area of the building except the ground floor area [41]. The test result indicates an air permeability of $1.32 \mathrm{~m}^{3} \cdot \mathrm{h}^{-1} \cdot \mathrm{m}^{-2}$, more than twice as the French mandatory level $\left(0.6 \mathrm{~m}^{3} \cdot \mathrm{h}^{-1} \cdot \mathrm{m}^{-2}\right.$ for a single-family house). This can be explained by the shrinkage of the timber frame structure which creates gaps at the joints between the frame elements and interior finishing of the walls. Thermogram of Fig. 4 shows an example of air leakage at the joints between the roof frame and the wall.

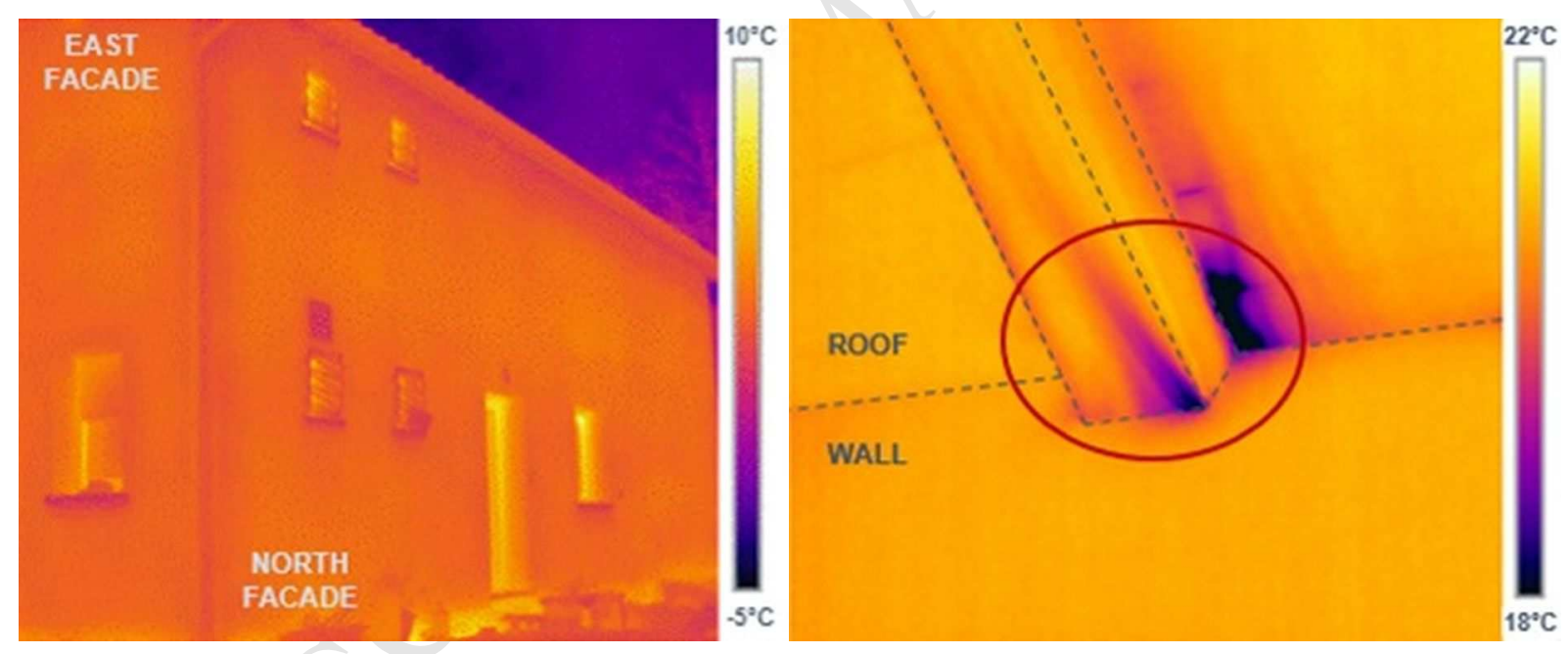

Fig. 4. Thermogram of the North and East facades of the building (on the left), and thermogram from the inside showing air leakages at the joint between the roof frame and the wall (on the right). 


\subsubsection{Hygrothermal comfort analysis}

Statistical summaries of measured outdoor and indoor air temperature and relative humidity are provided in Table $\mathbf{5}$ for the total experimental data set broken down by year and by season.

During the winter, the outdoor air temperature ranges globally from -7 to $25^{\circ} \mathrm{C}$ with mean values between 5 and $8^{\circ} \mathrm{C}$ over the four years. The outdoor air relative humidity is clearly high with mean values between 79 and $88 \% \mathrm{RH}$ over the four years because of the surrounded vegetation. The indoor air temperatures are homogeneous with mean values around $20^{\circ} \mathrm{C}$ in the ground floor rooms and $21^{\circ} \mathrm{C}$ in the first floor rooms. The temperature during the first year (2012) is slightly higher because the setpoint of the heating system was not correctly set. The mean values of indoor relative humidity range between 40 and $50 \% \mathrm{RH}$ with higher values in the bedroom 1 which is occupied by the parents (maximum about $60 \%$ ). During summer, the outdoor air temperature ranges globally from 4 to $38^{\circ} \mathrm{C}$ with mean values between 19 and $20^{\circ} \mathrm{C}$ over the four years. As for the winter, the outdoor air relative humidity is high with mean values between 70 and $79 \% \mathrm{RH}$ over the four years. The indoor air temperatures range from 19 to $27^{\circ} \mathrm{C}$. They are homogeneous with mean values around $23^{\circ} \mathrm{C}$ in the ground floor rooms and $24^{\circ} \mathrm{C}$ in the first floor rooms. The maximal indoor temperature never exceeds $27^{\circ} \mathrm{C}$ while the maximal outdoor temperature reaches $38^{\circ} \mathrm{C}$. The mean values of indoor relative humidity are higher and range between 55 and $60 \% \mathrm{RH}$ with maximal values of $76 \% \mathrm{RH}$.

During the mid-seasons, the indoor temperatures are also homogeneous with mean values between 22 and $23^{\circ} \mathrm{C}$. The indoor relative humidity values are as high as in summer with mean values between 47 and $60 \% \mathrm{RH}$. 


\begin{tabular}{|c|c|c|c|c|c|c|c|c|c|c|c|c|c|c|c|c|}
\hline & \multicolumn{4}{|c|}{2012} & \multicolumn{4}{|c|}{2013} & \multicolumn{4}{|c|}{2014} & \multicolumn{4}{|c|}{2015} \\
\hline & 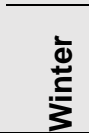 & $\begin{array}{l}\frac{9}{2} \\
\text { के }\end{array}$ & 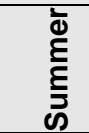 & 疍 & 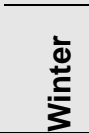 & 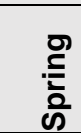 & 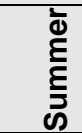 & 旁 & 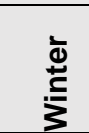 & $\begin{array}{l}\frac{D}{\bar{z}} \\
\text { के }\end{array}$ & 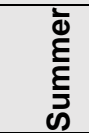 & 疍 & 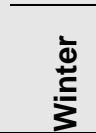 & $\frac{\text { 巳̆丶 }}{\text { के }}$ & 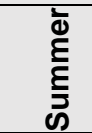 & $\begin{array}{l}\frac{c}{\xi} \\
\frac{3}{3} \\
\frac{Z}{\alpha}\end{array}$ \\
\hline \multicolumn{17}{|c|}{ Outdoor air temperature $\left[{ }^{\circ} \mathrm{C}\right]$} \\
\hline Mean & 7.7 & 13.9 & 19.6 & 10.3 & 4.7 & 12.5 & 19.7 & 15.3 & 7.0 & 14.2 & 19.2 & 6.5 & 5.8 & 14.6 & 19.4 & 10.5 \\
\hline S.D. & 5.1 & 5.7 & 5.5 & 5.9 & 4.4 & 5.3 & 5.5 & 5.0 & 4.6 & 5.4 & 4.4 & 3.0 & 4.8 & 6.0 & 6.2 & 5.2 \\
\hline Min & -5.7 & -1.0 & 3.6 & -7.0 & -5.4 & -1.5 & 7.2 & 0.6 & -7.1 & 0.3 & 8.0 & -1.6 & -6.7 & -1.0 & 5.7 & -4.5 \\
\hline $\operatorname{Max}$ & 24.6 & 30.1 & 35.8 & 27.6 & 18.8 & 30.0 & 35.2 & 27.2 & 20.8 & 30.0 & 34.1 & 12.7 & 21.0 & 33.9 & 37.8 & 23.0 \\
\hline \multicolumn{17}{|c|}{ Office air temperature $\left[{ }^{\circ} \mathrm{C}\right]$} \\
\hline Mean & 20.9 & 21.1 & 22.9 & 21.1 & 20.2 & 20.8 & 23.5 & 21.9 & 20.2 & 21.1 & 23.2 & 20.9 & 20.3 & 21.2 & 23.1 & 20.4 \\
\hline S.D. & 0.5 & 1.5 & 1.2 & 0.9 & 0.6 & 1.0 & 1.2 & 1.2 & 0.7 & 1.3 & 1.0 & 1.0 & 0.7 & 1.3 & 1.3 & 0.6 \\
\hline Min & 19.7 & 16.7 & 19.9 & 18.5 & 17.6 & 18.5 & 20.7 & 19.4 & 17.4 & 18.8 & 20.6 & 19.3 & 17.6 & 19.0 & 20.5 & 18.6 \\
\hline $\operatorname{Max}$ & 22.6 & 24.9 & 27.3 & 24.0 & 21.7 & 24.9 & 26.6 & 24.3 & 3.1 & 25.4 & 25.5 & 24.5 & 22.1 & 25.0 & 26.9 & 22.6 \\
\hline \multicolumn{17}{|c|}{ Living air temperature $\left[{ }^{\circ} \mathrm{C}\right]$} \\
\hline Mean & 21.7 & 21.8 & 23.2 & 21.6 & 20.4 & 21.3 & 23.5 & 22.5 & 20.7 & 21.6 & 23.5 & 21.3 & 20.4 & 21.5 & 23.2 & 21.1 \\
\hline S.D. & 1.0 & 1.5 & 1.2 & 1.1 & 0.9 & 1.1 & 1.2 & 1.3 & 0.8 & 1.3 & 1.1 & 1.2 & 0.9 & 1.3 & 1.5 & 1.1 \\
\hline Min & 19.4 & 17.2 & 18.9 & 15.8 & 18.1 & 19.1 & 19.5 & 19.3 & 18.0 & 19.6 & 19.1 & 18.9 & 18.0 & 18.7 & 18.5 & 18.8 \\
\hline $\operatorname{Max}$ & 24.4 & 25.8 & 27.2 & 25.4 & 23.4 & 24.4 & 26.9 & 25.5 & 22.9 & 26.1 & 26.2 & 24.4 & 24.9 & 25.8 & 27.2 & 29.3 \\
\hline \multicolumn{17}{|c|}{ Bedroom1 air temperature $\left[{ }^{\circ} \mathrm{C}\right]$} \\
\hline Mean & 21.1 & 21.5 & 23.2 & 21.1 & 19.6 & 20.9 & 23.1 & 22.5 & 19.9 & 21.1 & 23.0 & 20.8 & 19.5 & 21.2 & 22.9 & 20.6 \\
\hline S.L & 1.1 & 1.6 & 1.3 & 1.3 & 1.0 & 1.2 & 1.3 & 1.3 & 1.1 & 1.4 & 1.2 & 1.4 & 0.9 & 1.3 & 1.4 & 1.0 \\
\hline Min & 19.2 & 17.5 & 19.3 & 17.8 & 16.8 & 18.8 & 20.2 & 19.5 & 16.9 & 18.6 & 19.0 & 18.1 & 16.5 & 18.3 & 19.6 & 18.4 \\
\hline Max & 24.0 & 25.9 & 27.2 & 24.8 & 3.2 & 25.3 & 6.9 & 25.6 & 23.4 & 25.8 & 25.8 & 25.1 & 22.3 & 25.3 & 26.4 & 23.6 \\
\hline \multicolumn{17}{|c|}{ Bedroom4 air temperature $\left[{ }^{\circ} \mathrm{C}\right]$} \\
\hline Mean & 22.3 & 22.3 & 24.1 & 21.9 & 21.1 & 21.9 & 24.2 & 22.7 & 21.2 & 22.2 & 24.2 & 21.7 & 21.1 & 22.4 & 24.2 & 21.5 \\
\hline S.L & 0.8 & 1.5 & 1.3 & 1.0 & 0.7 & 1.1 & 1.4 & 1.4 & 0.7 & 1.3 & 1.1 & 1.1 & 0.7 & 1.3 & 1.4 & 0.6 \\
\hline M & 19.8 & 17.8 & 21.2 & 19.2 & 9.2 & 19.9 & 21.0 & 19.6 & 19.2 & 20.1 & 21.3 & 19.8 & 18.9 & 20.0 & 21.5 & 19.6 \\
\hline Max & 24.3 & 26.4 & 28.0 & 25.2 & 24.0 & 25.3 & 27.9 & 25.8 & 23.6 & 27.0 & 26.9 & 25.1 & 23.2 & 26.6 & 27.6 & 23.5 \\
\hline \multicolumn{17}{|c|}{ Outdoor air relative humidity [\%RH] } \\
\hline Mean & 79 & 76 & 70 & 90 & 88 & 79 & 74 & 89 & 84 & 75 & 79 & 93 & 88 & 76 & 75 & 88 \\
\hline S.D. & 21 & 20 & 19 & 11 & 15 & 18 & 19 & 11 & 18 & 19 & 17 & $\varepsilon$ & 14 & 20 & 19 & 12 \\
\hline Mir & 20 & 20 & 21 & 41 & 33 & 30 & 23 & 44 & 26 & 20 & 21 & 21 & 22 & 17 & 23 & 36 \\
\hline Max & 100 & 100 & 100 & 100 & 100 & 100 & 100 & 100 & 100 & 100 & 100 & 100 & 100 & 100 & 100 & 100 \\
\hline \multicolumn{17}{|c|}{ Office air relative humidity [\%RH] } \\
\hline Mean & 41 & 51 & 58 & 52 & 40 & 47 & 57 & 60 & 43 & 49 & 59 & 54 & 40 & 49 & 57 & 51 \\
\hline S. & 5 & 7 & 4 & 7 & 4 & 5 & 4 & 4 & 2 & 5 & 4 & 5 & 4 & 7 & 4 & 5 \\
\hline Min & 31 & 31 & 40 & 38 & 31 & 37 & 45 & 51 & 36 & 39 & 51 & 41 & 31 & 33 & 47 & 41 \\
\hline Max & 52 & 66 & 69 & 67 & 50 & 65 & 70 & 68 & 4 & 67 & 70 & 6 & 50 & 62 & 65 & 63 \\
\hline \multicolumn{17}{|c|}{ Living air relative humidity [\%RH] } \\
\hline Mean & 39 & 49 & 56 & 51 & 41 & 49 & 59 & 61 & 46 & 51 & 61 & 56 & 44 & 52 & 60 & 53 \\
\hline S.D. & 6 & 7 & 5 & 7 & 5 & 6 & 5 & 3 & 3 & 5 & 4 & 5 & 4 & 6 & 4 & 5 \\
\hline Mir & 28 & 2 & 34 & 34 & 3 & 35 & 43 & 52 & 4 & 39 & 49 & 4 & 32 & 33 & 49 & 38 \\
\hline Max & 52 & 69 & 73 & 70 & 52 & 68 & 73 & 68 & 55 & 72 & 76 & 67 & 54 & 69 & 72 & 67 \\
\hline \multicolumn{17}{|c|}{ Bedroom1 air relative humidity [\%RH] } \\
\hline Mean & 43 & 52 & 58 & 56 & 47 & 52 & 60 & 62 & 49 & 53 & 63 & 58 & 46 & 53 & 60 & 54 \\
\hline S.D. & 7 & 8 & 5 & 6 & 5 & 6 & 5 & 4 & 3 & 5 & 4 & 5 & 4 & 7 & 4 & 5 \\
\hline Min & 29 & 28 & 40 & 41 & 35 & 38 & 44 & 48 & 38 & 41 & 51 & 46 & 31 & 26 & 50 & 45 \\
\hline $\operatorname{Max}$ & 61 & 67 & 73 & 73 & 61 & 68 & 73 & 70 & 63 & 74 & 75 & 71 & 59 & 74 & 71 & 66 \\
\hline \multicolumn{17}{|c|}{ Bedroom4 air relative humidity [\%RH] } \\
\hline Mean & 34 & 47 & 54 & 56 & - & 47 & 55 & 60 & 43 & 48 & 57 & 54 & 41 & 48 & 56 & 51 \\
\hline S.D. & 3 & 7 & 4 & 5 & - & 5 & 4 & 3 & 2 & 5 & 4 & 5 & 4 & 6 & 4 & 5 \\
\hline Min & 28 & 29 & 35 & 45 & - & 36 & 43 & 51 & 33 & 38 & 47 & 42 & 33 & 32 & 46 & 41 \\
\hline Max & 41 & 64 & 66 & 68 & - & 63 & 66 & 67 & 50 & 64 & 68 & 67 & 49 & 62 & 65 & 64 \\
\hline
\end{tabular}

Table 5. Statistical summary of indoor and outdoor air temperature and relative humidity

(S.D.: Standard-Deviation). 
Fig. 5 shows the statistical results of the measured indoor air temperature and relative humidity in the living room for the total experimental data set broken down by year and by month. Each box represents the main statistical results for each month of the 4-year period of measurement (from February 2012 till December 2015). The median is represented by the central mark (red line). The lower and upper edges of the box are the $25^{\text {th }}\left(1^{\text {st }}\right.$ quartile) and $75^{\text {th }}$ percentiles ( $3^{\text {rd }}$ quartile) respectively. The whiskers extend to the most extreme data points not considered outliers (approximately \pm 2.7 times the standard-deviation). The outliers are plotted individually by the red crosses.

Globally, the annual trends of indoor temperature and relative humidity are similar over the four years for the living room. The measurements show the same result for the other rooms.

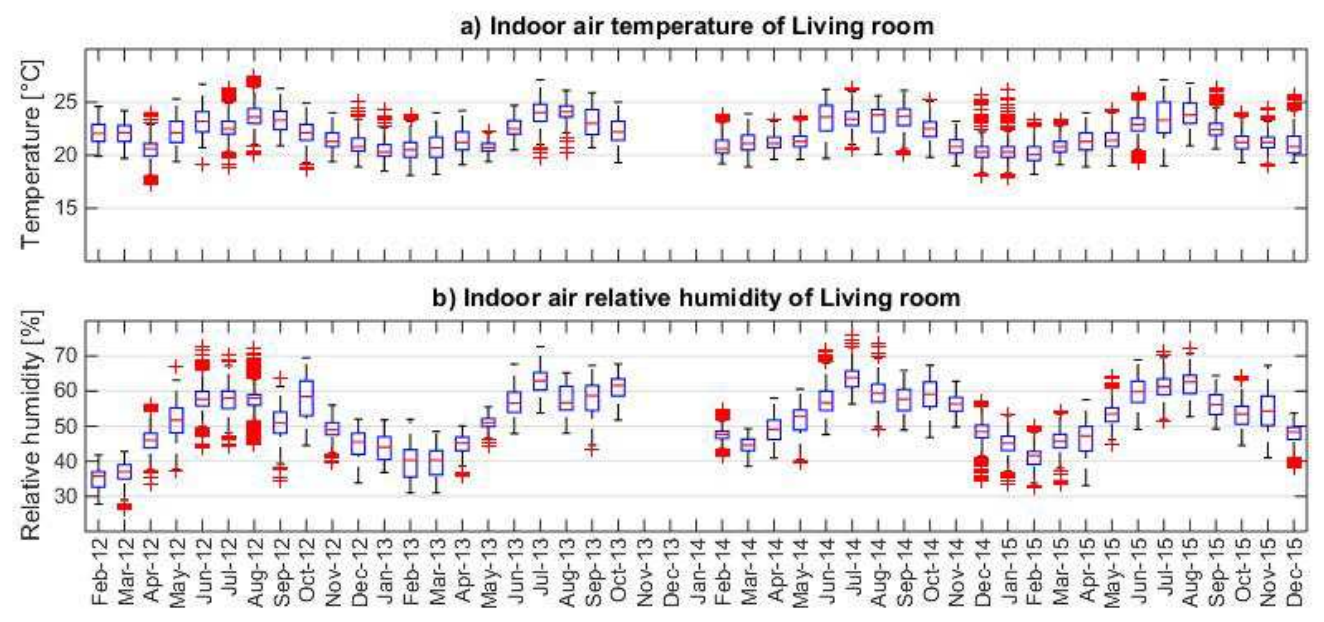

Fig. 5. Statistical monthly results of the measured indoor air temperature (a) and relative humidity (b) in the living room.

In order to analyze the thermal comfort, the EN 15251 standard [42] was used. The standard defines four categories of comfort depending on the level of expectation: category I for spaces occupied by very sensitive and fragile person, category II for new buildings, category III for existing buildings used as reference in this study, and category IV for values outside the previous categories. The category IV corresponds to discomfort, and values in this 


\section{ACCEPTED MANUSCRIPT}

category are only accepted for a limited part of the measurement period (5\% of occupied hours).

The measured psychrometric data of the living room are presented in Fig. 6 for the winter and summer periods respectively. The boundary of the comfort zone (category III) are also shown on the figures. During winter, measurements of temperature and relative humidity are located in the comfort zone almost all the time for the four years. Temperature never exceeds the upper limit of comfort zone $\left(25^{\circ} \mathrm{C}\right)$. It falls below the lower limit $\left(19^{\circ} \mathrm{C}\right)$ less than $5 \%$ of occupancy time. The relative humidity values never exceed the upper and lower limits of comfort zone avoiding the risk of dry air. For summer periods, the situation is different. Temperature values never exceed the upper limit of comfort $\left(27^{\circ} \mathrm{C}\right)$. They fall below the lower limit $\left(22^{\circ} \mathrm{C}\right)$ during $12 \%$ of time over the four years. This should not harm the summer thermal comfort as lower temperature can be considered as pleasant during summer. Humidity ratio values exceed 12 g.kg-1 dry air during $16 \%$ of occupancy time over the four years. However, relative humidity values remain below $70 \% \mathrm{RH}$ avoiding mold growth [43].
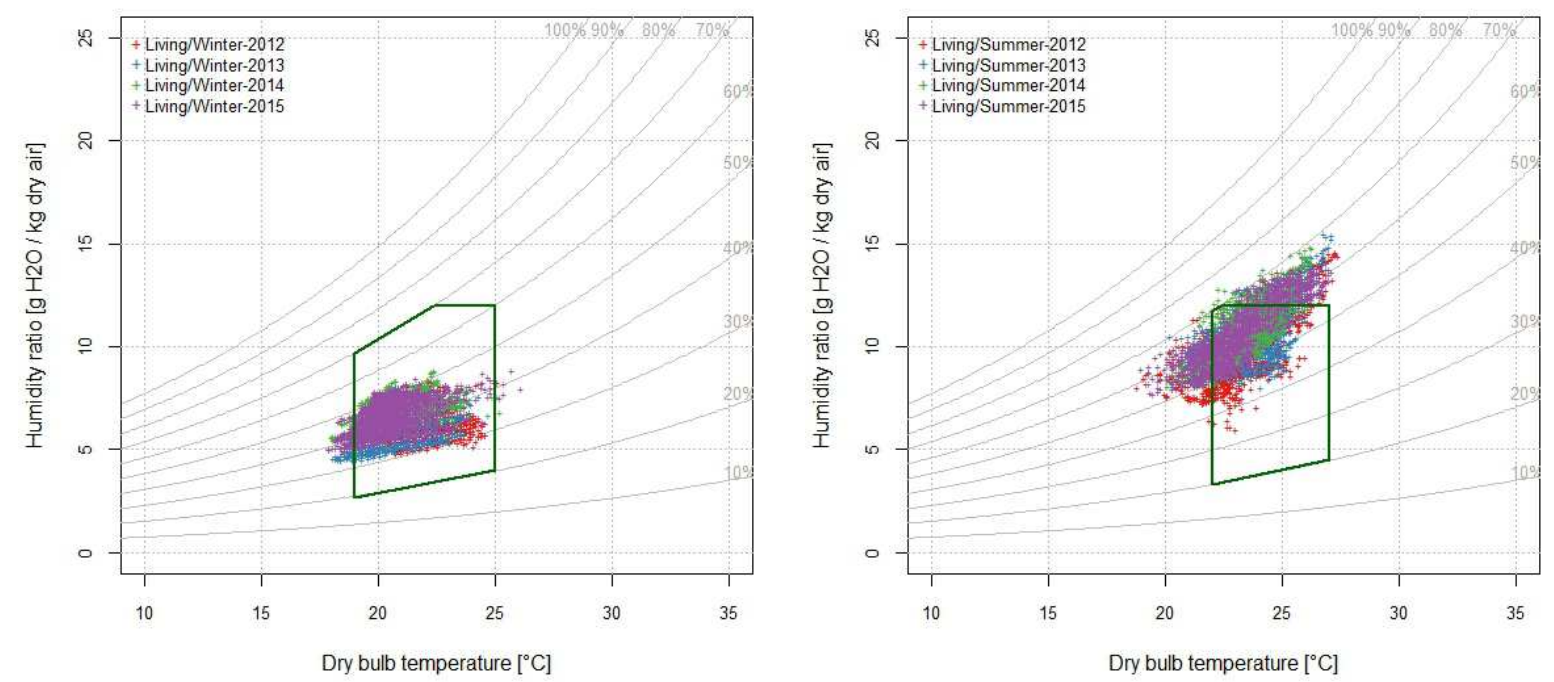

Fig. 6. The measured psychrometric data of the living room for the winter periods (left) and the summer periods (right) from 2012 till 2015. The green polygons illustrate the winter and summer comfort zones of the EN 15251 standard. 


\section{ACCEPTED MANUSCRIPT}

Finally, the indoor air temperature and relative humidity of different rooms were analyzed and compared to the comfort zones of the EN 15251 standard [42] as shown in Fig. 7 for each of the different winter and summer periods. We only considered the lower limit of comfort zone for winter, and the upper limit of comfort zone for summer. The measurements of different rooms showed a good level of thermal comfort with values in category IV less than $5 \%$ of occupied hours, except the bedroom1 during winter as the parents set lower temperature during night. 
Winter-2012

$\square$ Cat. I $\square$ Cat. II $\square$ Cat. III $\square$ Cat. IV

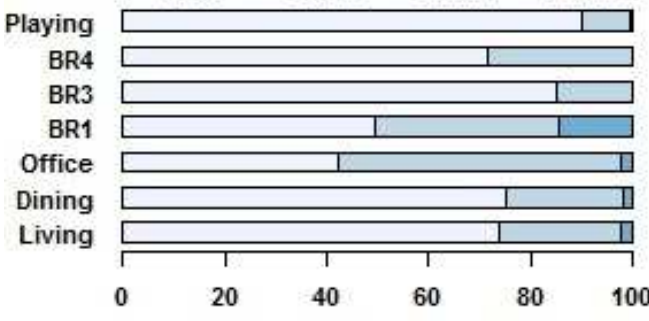

Percentage of occupancy time [\%]

Winter-2013

$\square$ Cat. I $\square$ Cat. II $\square$ Cat. III $\square$ Cat. IV

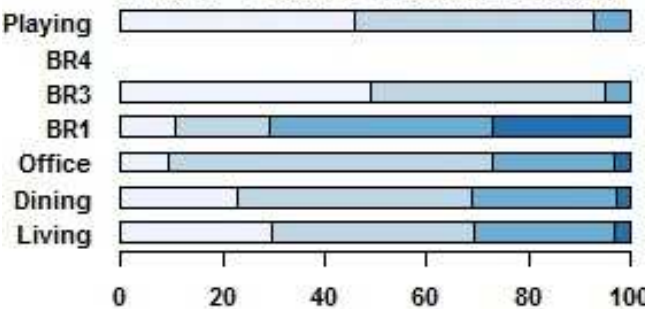

Percentage of occupancy time [\%]

Winter-2014

$\square$ Cat.I $\square$ Cat. II $\square$ Cat. III $\square$ Cat. IV

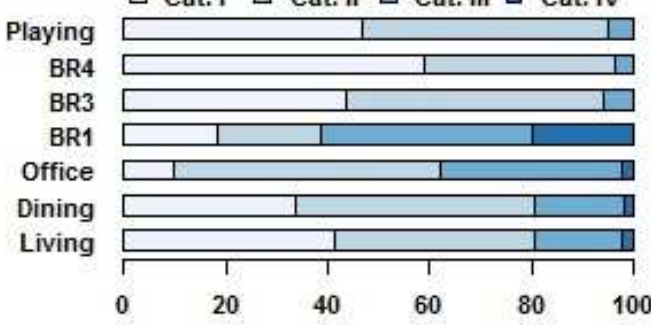

Percentage of occupancy time [\%]

Winter-2015

$\square$ Cat. I $\square$ Cat. II $\square$ Cat. III $\square$ Cat. IV

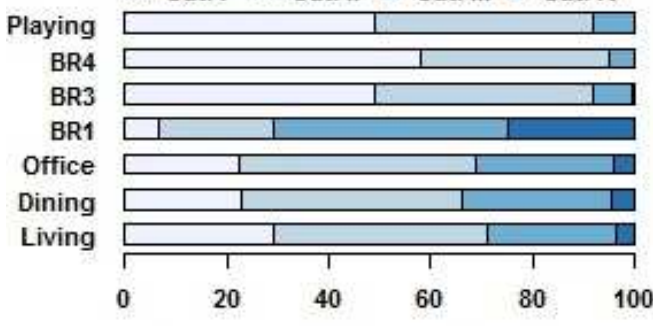

Percentage of occupancy time [\%]
Summer-2012

$\square$ Cat. I $\square$ Cat. II $\square$ Cat. III $\square$ Cat. IV

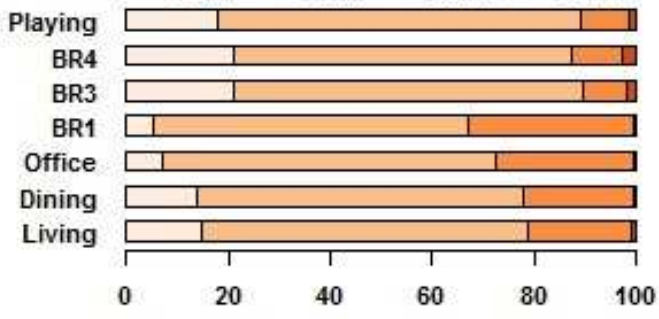

Percentage of occupancy time [\%]

Summer-2013

$\square$ Cat. I $\square$ Cat. II $\square$ Cat. III $\square$ Cat. IV

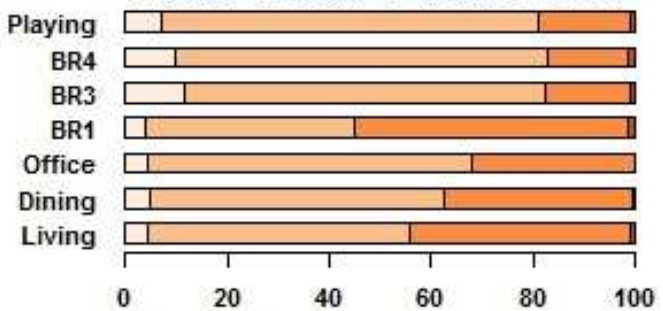

Percentage of occupancy time [\%]

\section{Summer-2014}

$\square$ Cat. I $\square$ Cat. II $\square$ Cat. III $\square$ Cat. IV

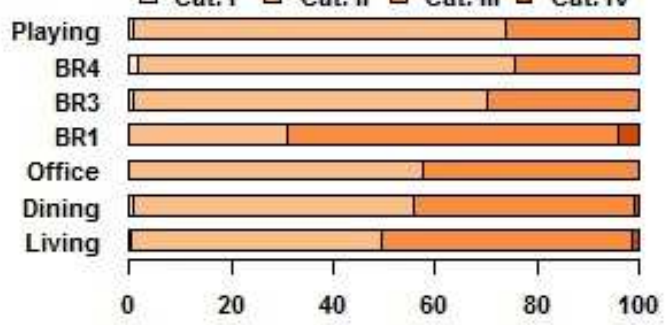

Percentage of occupancy time [\%]

Summer-2015

$\square$ Cat. I $\square$ Cat. II $\square$ Cat. III $\square$ Cat. IV

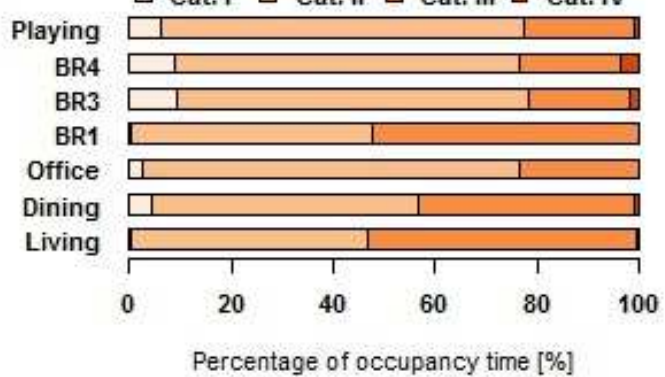

Fig. 7. Quality of thermal environment in percentage of occupancy time in the four categories of the EN 15251 standard. 


\subsubsection{Hygrothermal behavior of the north and west walls}

Fig. 8 and Fig. 9 show the statistical results of the measured relative humidity and temperature of the outdoor air, the North-facing wall at $25 \mathrm{~cm}$ depth (near the outdoor surface) and $15 \mathrm{~cm}$ depth (in the middle of the wall), and the indoor air near the wall. The full experimental data set is broken down by year and by month.
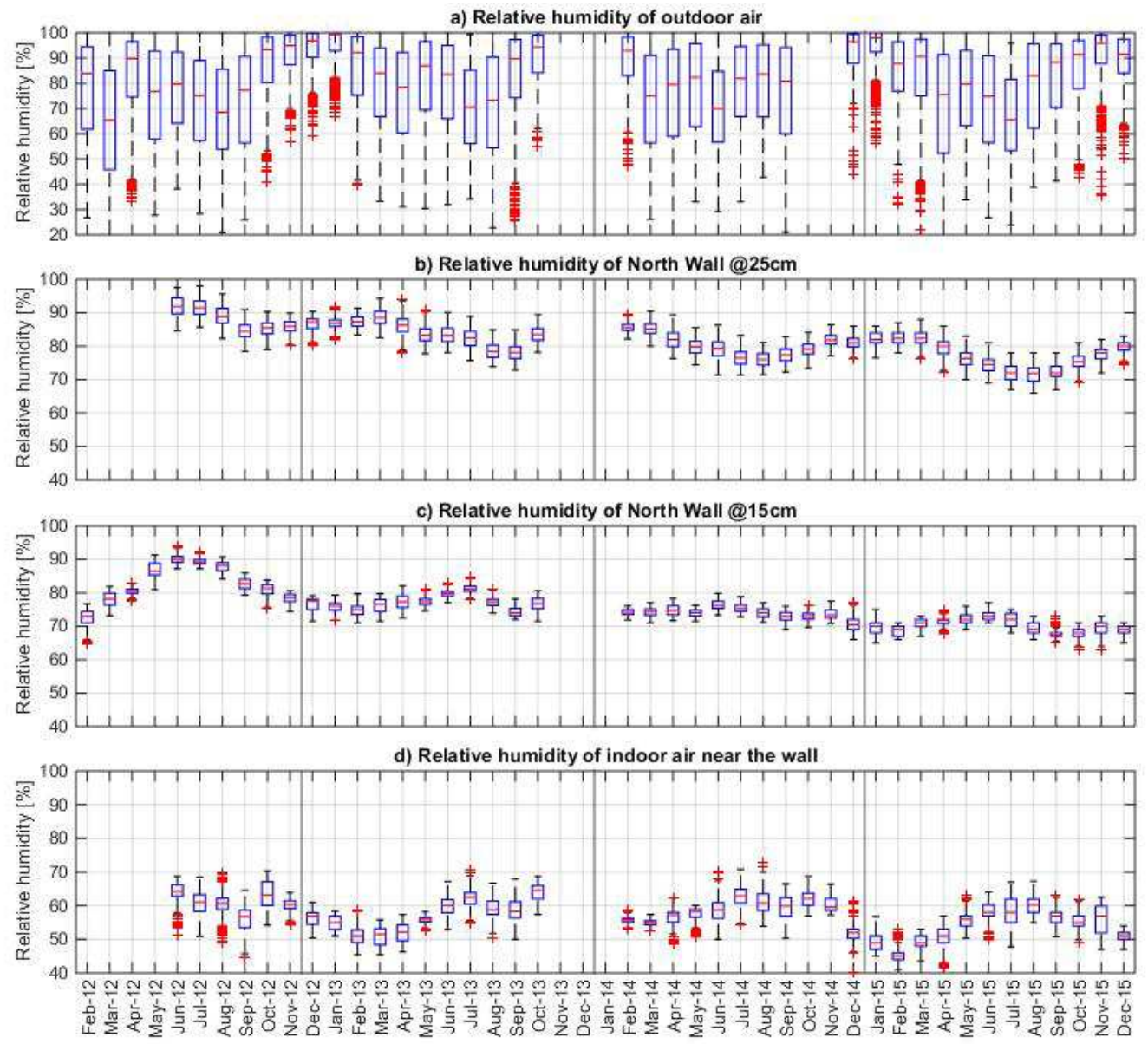

Fig. 8. Statistical monthly results of the measured relative humidity of the outdoor air (a), the North wall at $25 \mathrm{~cm}$ depth (b) and $15 \mathrm{~cm}$ depth (c), and the indoor air near the wall (d).

For the relative humidity at $15 \mathrm{~cm}$ depth, the highest values are reached during the first year (2012) with maximum variations: minimum value around 65\% during winter up to a maximum value around $95 \%$ during summer. After the first year, relative humidity variations are dampened and monthly median values continue to slowly decrease from year to year. The median value falls from $75 \%$ in February 2013 to $70 \%$ in February 2015 , and from $80 \%$ in 


\section{ACCEPTED MANUSCRIPT}

June 2013 to $73 \%$ in June 2015 . Besides, monthly values of wall relative humidity vary in a narrow range (5\% to $10 \%)$ regarding the monthly variation of outdoor relative humidity (up to $80 \%)$.

The higher values of relative humidity during the first year could be explained by the fact that the HLC wall was still drying even though the measurements were undertaken one year after the walls construction. In fact, the lime-sand plaster was applied shortly after the walls construction. Besides the outdoor $\mathrm{RH}$ showed high values over the period of the measurements (daily average varies between 60 and 95\%). This could induce a significantly longer drying time.
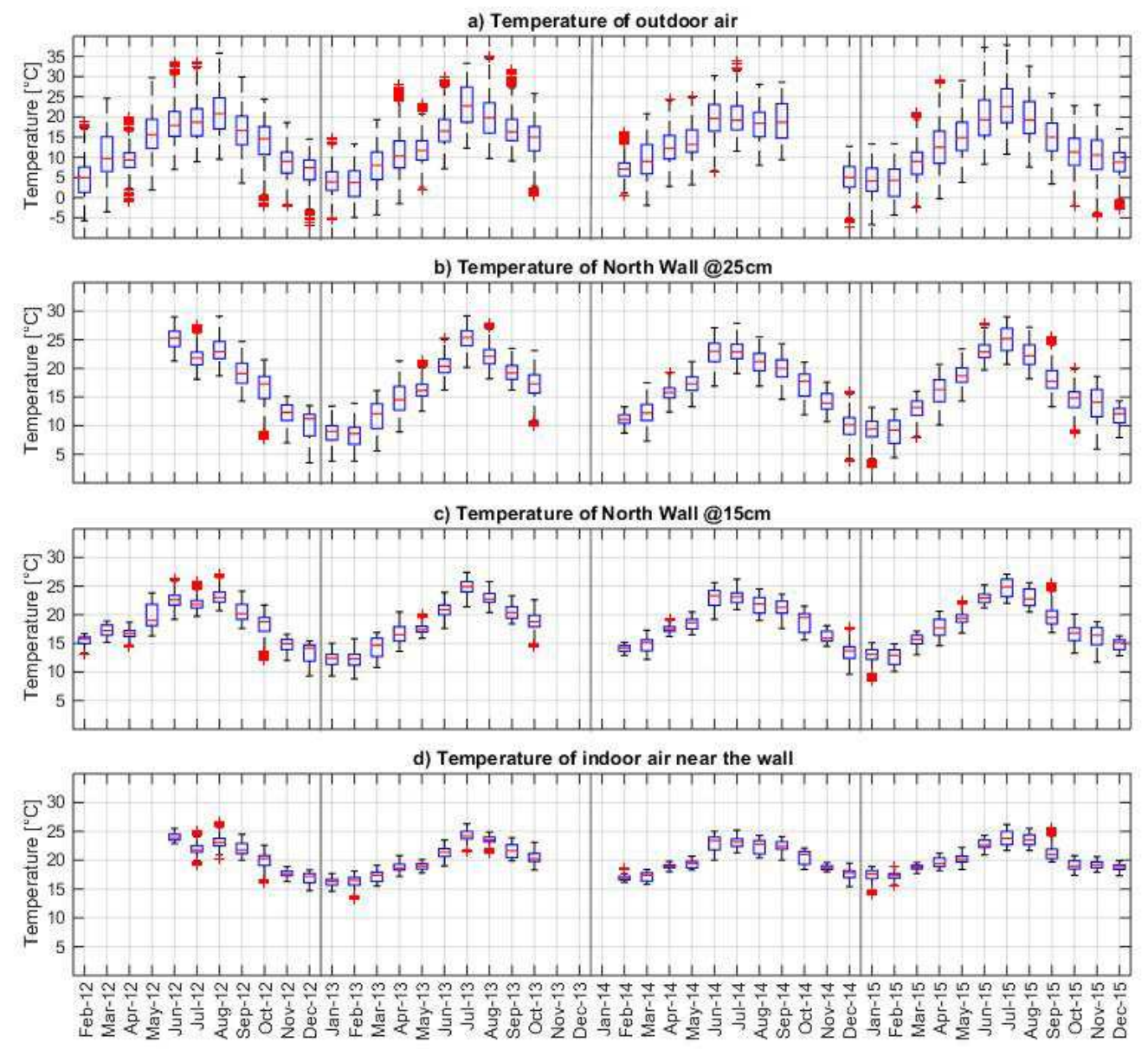

Fig. 9. Statistical monthly results of the measured temperature of the outdoor air (a), the North wall at $25 \mathrm{~cm}$ depth (b) and $15 \mathrm{~cm}$ depth (c), and the indoor air near the wall (d). 


\section{ACCEPTED MANUSCRIPT}

Unlike relative humidity, wall temperature values at $15 \mathrm{~cm}$ depth show almost no variation from year to year with monthly median values around $13^{\circ} \mathrm{C}$ in winter and $25^{\circ} \mathrm{C}$ in summer. Yearly values of wall temperature range from $10^{\circ} \mathrm{C}$ to $25^{\circ} \mathrm{C}$ while the outdoor temperature values range from less $-5^{\circ} \mathrm{C}$ to more than $35^{\circ} \mathrm{C}$. Similarly, the monthly variations of wall temperature were much lower regarding the variations of outdoor temperature $\left(5^{\circ} \mathrm{C}\right.$ against $\left.20^{\circ} \mathrm{C}\right)$

The measured temperature and relative humidity at $25 \mathrm{~cm}$ depth of the North-facing wall (near the outdoor surface) show the same annual trend with higher values and higher variations than in the middle of the wall. Relative humidity of the wall at $25 \mathrm{~cm}$ depth seems to be more influenced by outdoor air conditions than at $15 \mathrm{~cm}$ depth.
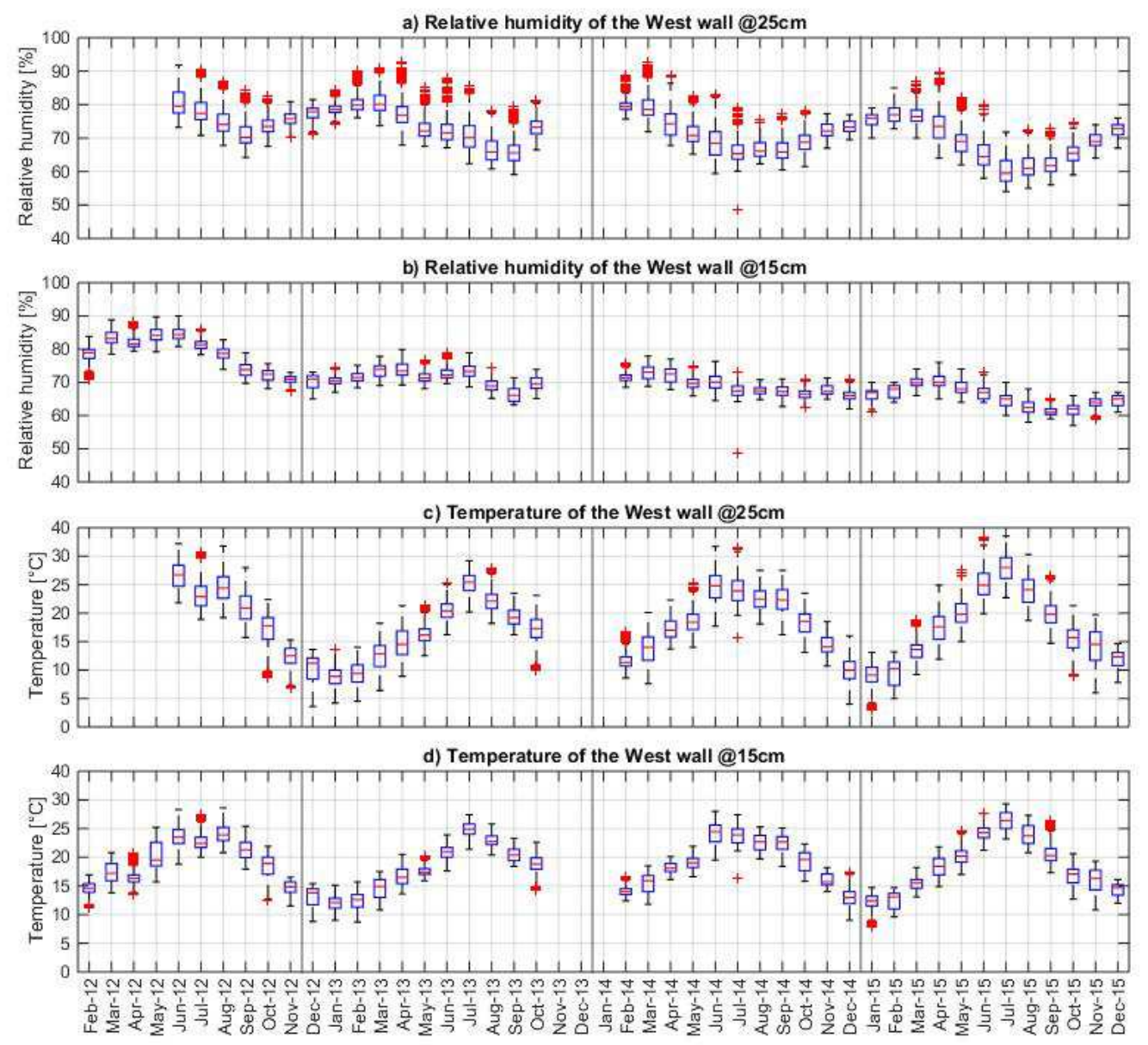

Fig. 10. Statistical monthly results of relative humidity and temperature of the West wall at 25 cm depth (a, c) and $15 \mathrm{~cm}$ depth (b, d). 


\section{ACCEPTED MANUSCRIPT}

Fig. 10 shows the statistical results of the measured relative humidity and temperature of the West-facing wall at $25 \mathrm{~cm}$ depth (near the outdoor surface) and $15 \mathrm{~cm}$ depth (in the middle of the wall). The total experimental data set is broken down by year and by month.

Regarding the West-facing wall which is more exposed to solar radiations, measurements at both depths showed the same trend as the North-facing wall with more variations and slightly lower relative humidity and slightly higher temperature.

a

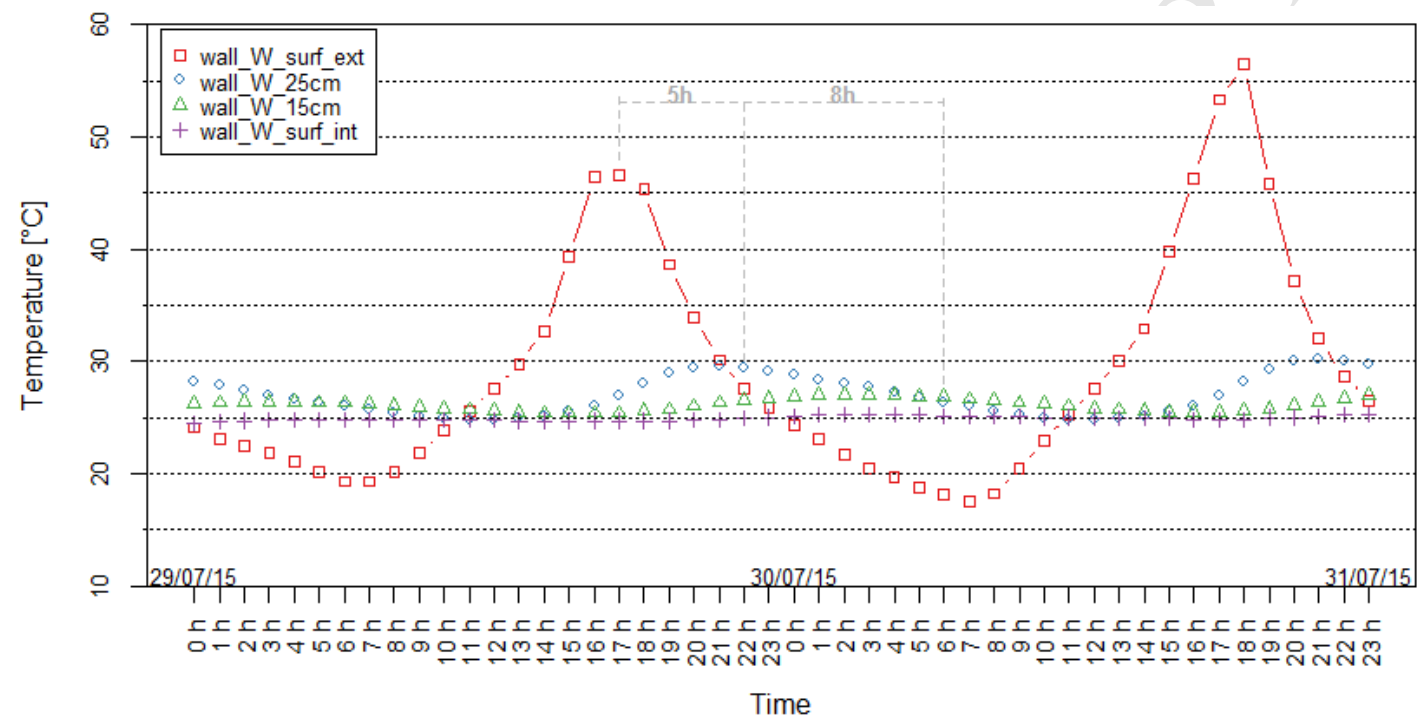

b

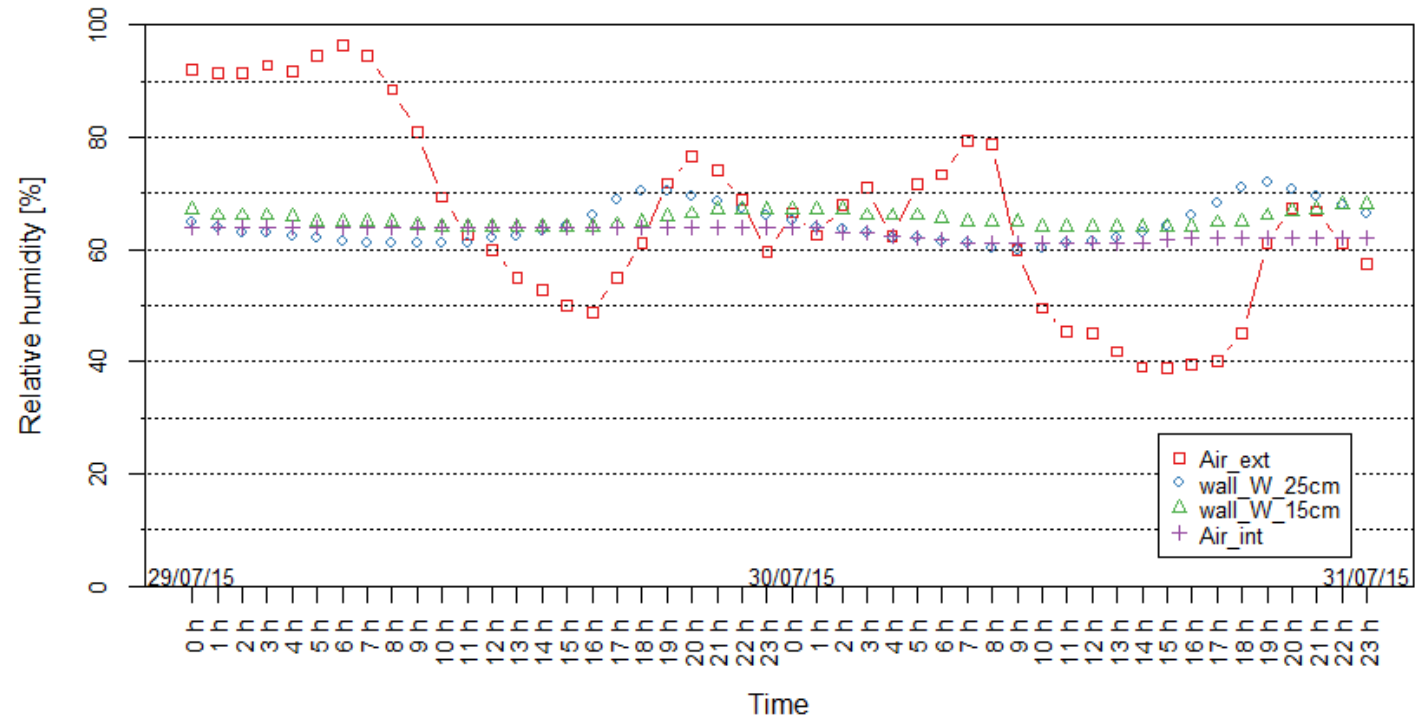

Fig. 11. Hourly temperature (a) and relative humidity (b) within the west-facing wall from $29^{\text {th }}$ to $31^{\text {st }}$ July 2015 . 
Moreover, Fig. 11 shows that the wall is able to dampen the outside daily variations by $90 \%$ and to delay the effects of peak values about a dozen of hours. Similar trends are also observed in winter. This result confirms the good thermal inertia of $30 \mathrm{~cm}$ thick HLC walls.

\subsection{Experimental versus numerical results}

Simulations are set up during a period of one year from $1^{\text {st }}$ January 2015 to $31^{\text {st }}$ December 2015. Measured indoor (in the office room) and outdoor temperatures and relative humidities are presented respectively in Fig. 12a and Fig. 12b. The wind velocity and the global and diffuse solar radiations measured on site are respectively represented in Fig. 12c and Fig. 12d. Meteonorm weather files for the city of Bergerac (located at $40 \mathrm{~km}$ from the site) are selected to consider short wave solar radiation. The short wave solar absorption coefficient is set to 0.6.

Standard interior surface exchange coefficients are quite representative of the effective values considering natural convection on a vertical wall located in a room at ambient temperature around $20^{\circ} \mathrm{C}$ and, at a lesser degree, radiative contribution of the house lighting. The exterior surface of the wall is subjected to natural convection due to the thermal gradient between exterior air and the wall surface temperature, to forced convection due to wind, to solar radiation and to wind-driven rain. All these phenomena are significantly weatherdependent and may highly fluctuate during all the year. In order to evaluate the impact of these exterior phenomena on the relative humidity and temperature evolutions, a set of correlations detailed in [32] have been implemented to consider natural and forced (considering wind effects) convections and long wave solar radiative exchange. The results, not presented in this paper, show that under the studied climatic conditions, the standard heat and moisture exchange coefficients are quite able to represent the surface exchange.

The standard interior and exterior heat exchange coefficients considered in the simulations are thus chosen respectively at 7.7 and $25 \mathrm{~W} \cdot \mathrm{m}^{-2} \cdot \mathrm{K}^{-1}$. The interior and exterior surface moisture exchange coefficients are respectively $2.510^{-8}$ and $1.310^{-7} \mathrm{~kg} \cdot \mathrm{Pa}^{-1} \cdot \mathrm{m}^{-2} \cdot \mathrm{s}^{-1}$. 

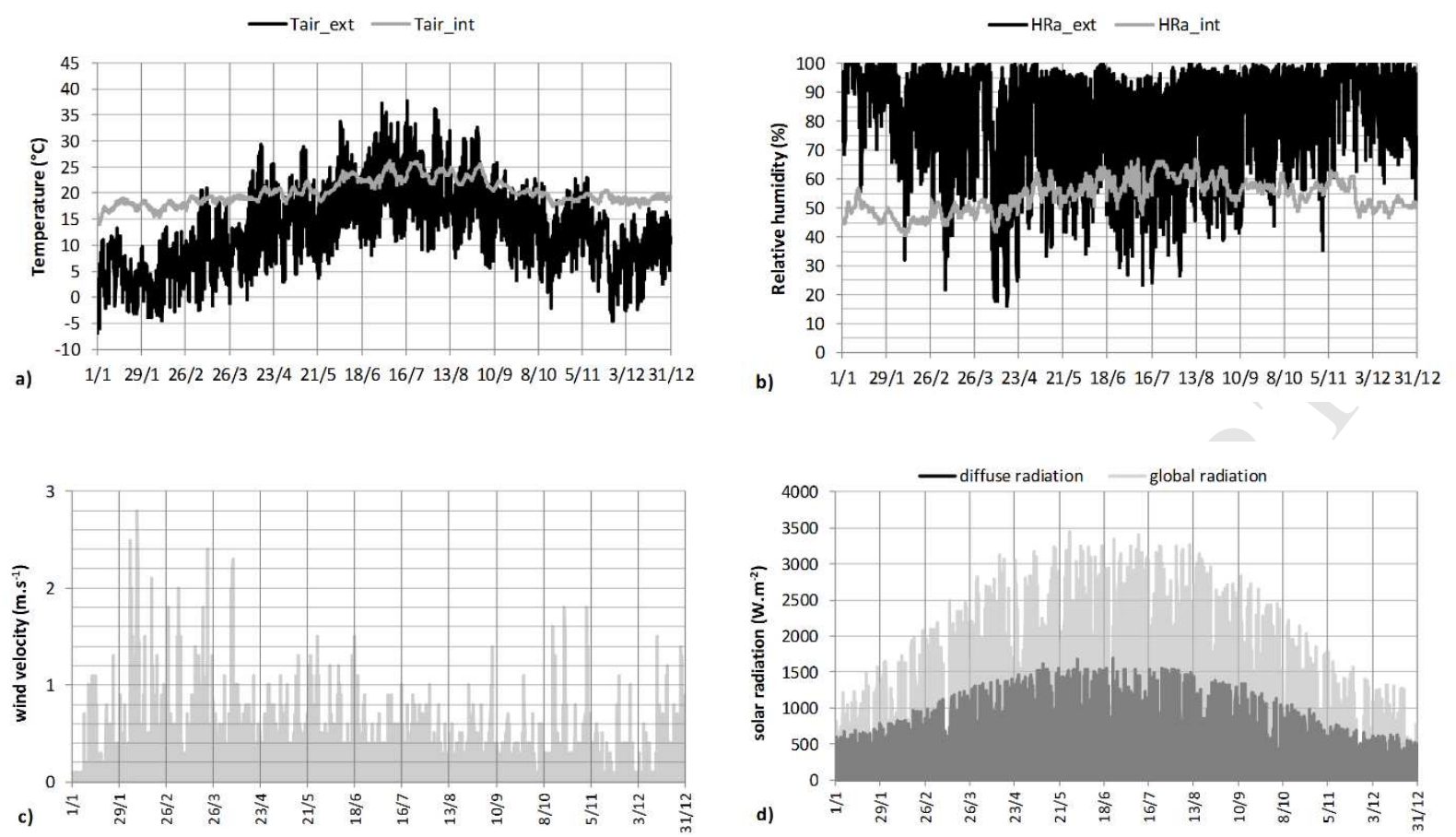

Fig. 12. : Evolution of the exterior and interior temperatures a), relative humidity b), wind velocity $c)$, and solar radiations b) measured on site for the north wall.

\subsubsection{Comparison between Wufi and Matlab numerical results}

In this section, the hygrothermal response of the north wall is simulated with Wufi and Matlab and the numerical results are compared with the experimental ones.

The initial temperature of the wall is $20^{\circ} \mathrm{C}$ and the initial relative humidity $65 \% \mathrm{RH}$. These values are the average ones measured in the wall the $1^{\text {st }}$ January 2015 at midnight.

For a reason of readability, Fig. $13 \mathrm{a}$ and Fig. $13 \mathrm{~b}$ show the evolution of temperature respectively at $25 \mathrm{~cm}$ and $15 \mathrm{~cm}$ depth during August, and Fig. 13c and Fig. 13d during March. Fig. 14a and Fig. 14b show the evolution of the relative humidity and Fig. 14c and Fig. $14 \mathrm{~d}$ the evolution of temperature throughout the year respectively at $25 \mathrm{~cm}$ and $15 \mathrm{~cm}$ depths.

Concerning temperature evolutions, the results show a quite good agreement between Wufi and Matlab simulations. However, during winter the simulated temperatures are lower by 2$3^{\circ} \mathrm{C}$ than the experimental ones and their amplitude of variation is higher. 

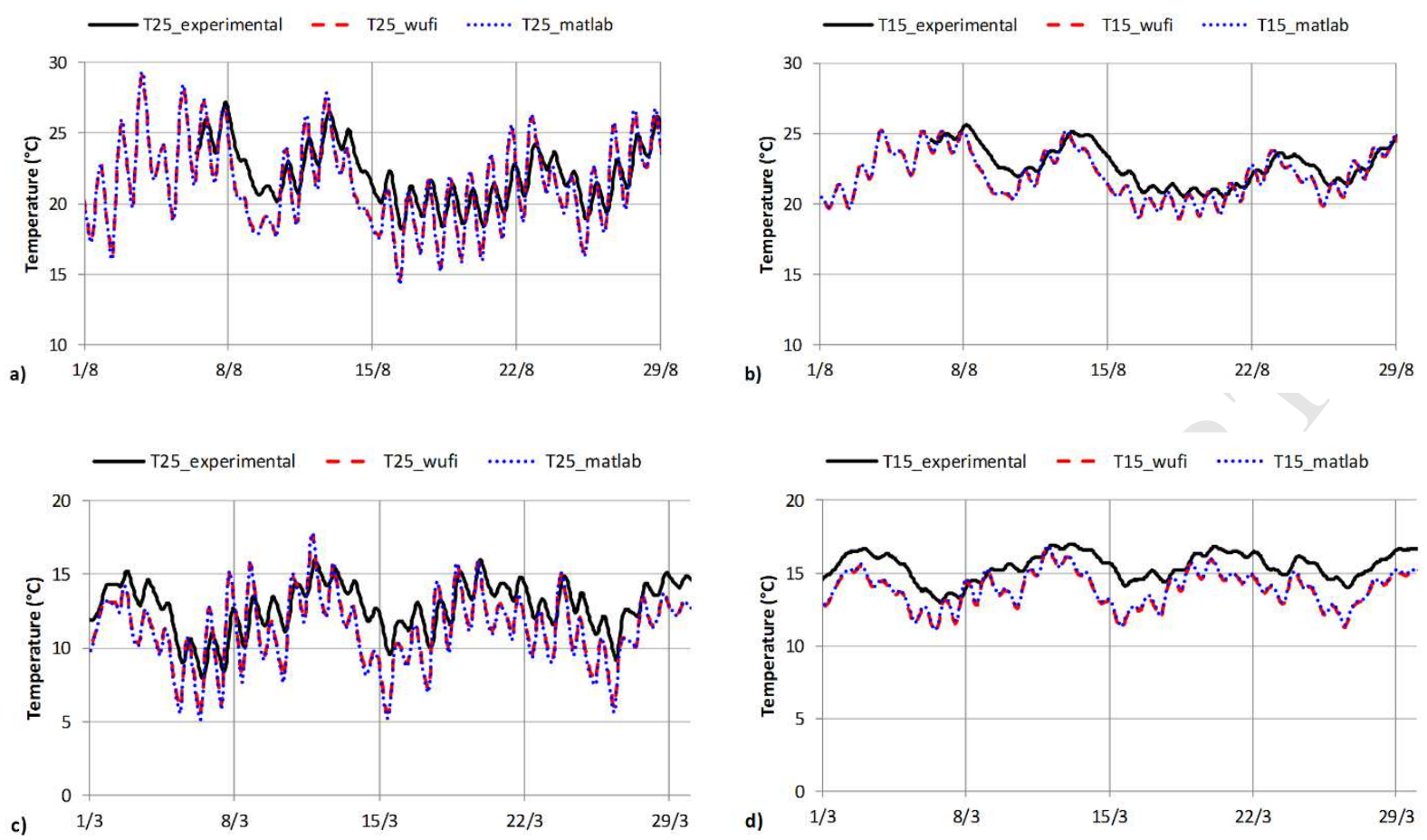

Fig. 13. : Evolution of the temperature at $25 \mathrm{~cm}$ depth in August a), at $15 \mathrm{~cm}$ depth in August b), at $25 \mathrm{~cm}$ depth in March c), at $15 \mathrm{~cm}$ depth in March d). The black solid line stands for the experimental values, the red dashed line for the simulated results obtained with Wufi and the blue points line for the simulated results obtained with Matlab.

As for the temperature evolution, the simulated results obtained with Matlab concerning the evolution of relative humidity are in a quite good agreement with the simulated results obtained with Wufi. The discrepancies between Wufi and Matlab results can be explained by the fact that the moisture content and the liquid transport coefficient are not similarly implemented. In Matlab, analytical equations are used to model the evolutions of the moisture content and of the liquid transport coefficient (which depends on moisture content), whereas in Wufi, a numerical table with logarithmic interpolation between the table values is used. 

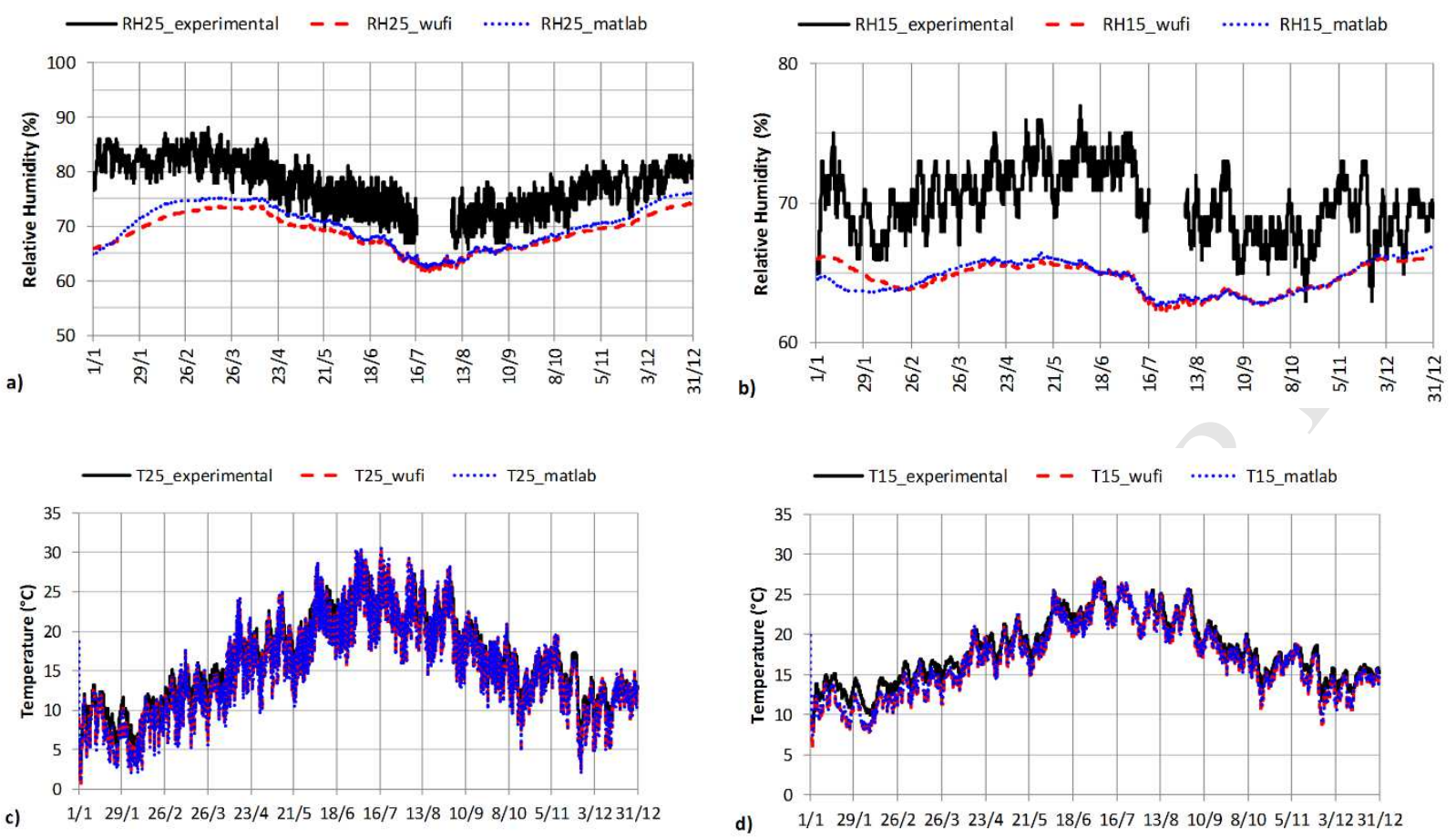

Fig. 14. : Evolution of the relative humidity at $25 \mathrm{~cm}$ depth a) and at $15 \mathrm{~cm}$ depth b) and temperature at $25 \mathrm{~cm}$ depth $\mathrm{c}$ ) and at $15 \mathrm{~cm}$ depth d) from $1^{\text {st }}$ January to $31^{\text {st }}$ December 2015.

Furthermore, as observed in [28], Wufi and Matlab simulations are not able to reproduce daily variations. Nevertheless, in comparison with the experimental data, the results show that Wufi and Matlab simulations allow well reproducing the yearly global trend of the evolution of the relative humidity even though the simulated results are lower from $5 \%$ to $15 \% \mathrm{RH}$ than the experimental results. At $25 \mathrm{~cm}$, during the stage of desorption from February to July, experimental and numerical relative humidities slightly decrease then increase during the stage of adsorption from July to January. However, at $15 \mathrm{~cm}$ depth, some differences can be observed: a delay occurs between the stages of adsorption and desorption when the numerical results are compared to the experimental ones. Several reasons can explain this difference. First, the models do not consider the hysteresis phenomenon which occurs during the sorption process. Kwiatkowski [44] confirms through a sensitivity analysis that, in realistic conditions, neglecting hysteresis leads to an overestimation of the moisture buffering properties of the material. The temperature 
variations have also an impact on the sorption process $[21,27,45]$ and may significantly influence the evolution of relative humidity through the wall.

These elements are investigated and discussed in the following sections with the Matlab model.

\subsubsection{Influence of hysteresis and hygric history}

In this paragraph, hysteresis phenomenon is considered. The influence of this phenomenon is discussed from Matlab simulations. The Huang's hysteresis model associated with the Van Genuchten model, selected to represent HLC hygric sorption process, is implemented in the heat and moisture transfer model.

First, the simulation with hysteresis is performed from $1^{\text {st }}$ January 2015 to $31^{\text {st }}$ December 2015 from the initial conditions described in the previous paragraph. Temperature evolutions are not presented but hysteresis does not create significant modifications in this case.
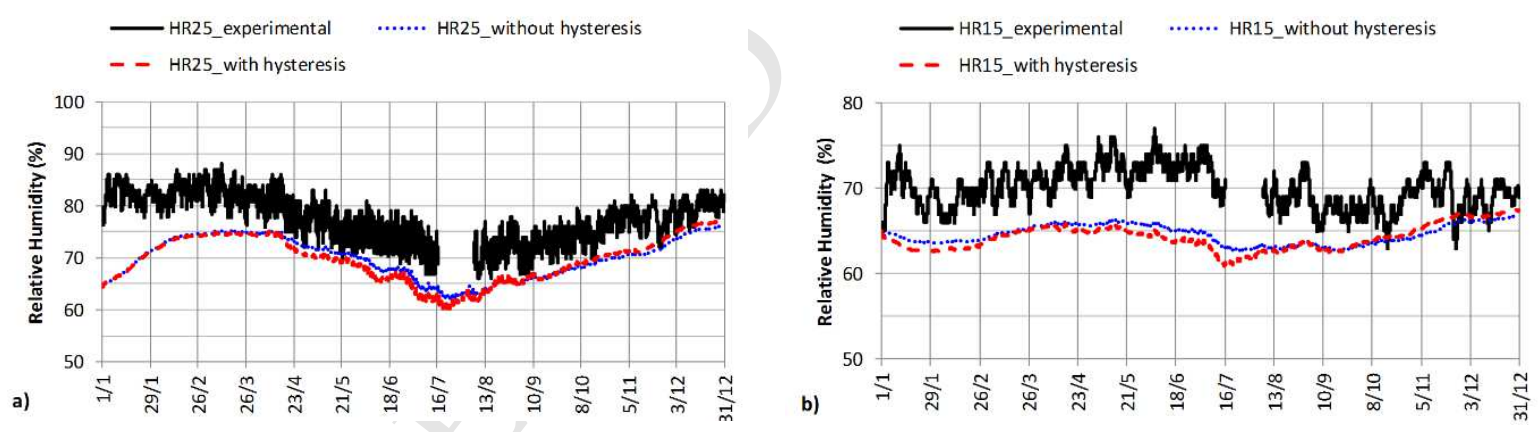

Fig. 15. : Evolution of the relative humidity at $25 \mathrm{~cm}$ depth a) and at $15 \mathrm{~cm}$ depth b) from $1^{\text {st }}$ January to $31^{\text {st }}$ December 2015 . The black solid line stands for the experimental values, the red dashed line for the simulated results obtained with hysteresis and the blue points line for the simulated results obtained without hysteresis

Fig. 15a and Fig. 15b show for both studied depths that there occur few differences in relative humidity evolution with or without hysteresis consideration. In order to explain the differences observed without and with hysteresis, the simulated evolution of relative humidity 


\section{ACCEPTED MANUSCRIPT}

at $25 \mathrm{~cm}$ depth is analyzed. During the first adsorption stage from $1^{\text {st }}$ January at $65 \% \mathrm{RH}$ to $15^{\text {th }}$ April, both approaches considering or not hysteresis follow the main adsorption curve. This explain why the evolution of relative humidity is the same during this period. Then, during the desorption stage from $15^{\text {th }}$ April to $20^{\text {th }}$ July, with hysteresis, moisture content does not follow the main adsorption curve but a primary desorption curve. Consequently, the hygric capacity is reduced which explains the evolution of relative humidity. Finally, during the second stage of adsorption from $20^{\text {th }}$ July to $31^{\text {st }}$ December, moisture content follows a secondary adsorption curve. This curve has also a reduced hygric capacity in comparison with the main adsorption curve, case for which hysteresis is not considered.

Then, in order to evaluate the influence of the previous hygrothermal variations, the simulations are performed from the $1^{\text {st }}$ July 2012 (date of the beginning of the experimental campaign) to the $31^{\text {st }}$ December 2015 . The results are still presented from $1^{\text {st }}$ January 2015 to $31^{\text {st }}$ December 2015 in Fig. 16a and Fig. 16b only concerning the relative humidity evolution.
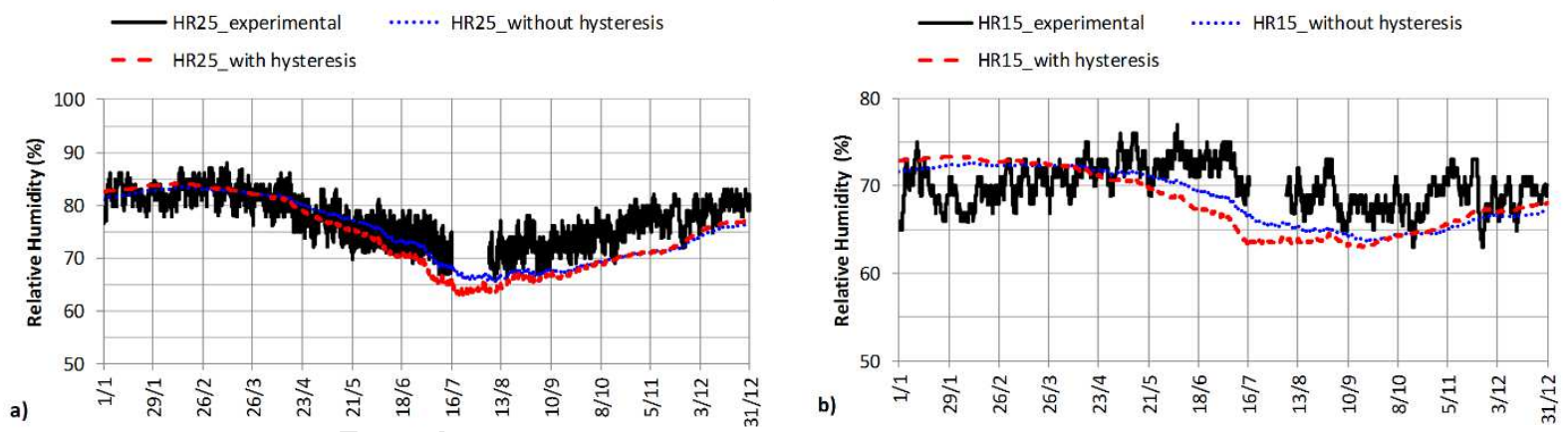

Fig. 16. Evolution of the relative humidity at $25 \mathrm{~cm}$ depth a) and at $15 \mathrm{~cm}$ depth b) from $1^{\text {st }}$ January to $31^{\text {st }}$ December 2015 considering the previous hygrothermal variations from the $1^{\text {st }}$ July 2012.

For both models with or without hysteresis, the consideration of the hygric history lived by the wall before the $1^{\text {st }}$ January 2015 allow finding a better agreement between experimental and 
numerical results especially at $25 \mathrm{~cm}$ depth. This is explained by a better estimation of the initial relative humidity and temperature through the wall at the beginning of the simulation.

Despite a more physical and realistic description of the sorption process, numerical results obtained with or without hysteresis are equivalent. Under these hygrothermal conditions, the relevance to consider hysteresis phenomenon is poor. Indeed, the variations of outside and inside hygrothermal conditions are not enough high to observe an effective influence of the hysteresis consideration on the relative humidity and temperature evolution through the wall.

\subsubsection{Influence of temperature-dependent sorption process}

The influence of the temperature effect on moisture content is analyzed in this section with and without hysteresis. The model based on the Clausius-Clapeyron equation and the Powers and Brownyard relation used to express the evolution of the isosteric heat is implemented in the heat and moisture transfer model.

Starting from the effective initial relative humidity and temperature determined in the previous paragraph with the hygric history consideration, two simulation runs are performed considering the temperature effect on sorption process, with and without hysteresis. The results are compared with the experimental data and the standard simulation results obtained when hysteresis and temperature effect on sorption are not considered.

Temperature evolutions are not represented but, as observed in [45], few differences occur in the evolution of the temperature with or without consideration of the temperature effect on sorption process.

Fig. 17a and Fig. 17b which compare the evolution of the relative humidity with the evolution of temperature for 3 days from the $1^{\text {st }}$ June to the $4^{\text {th }}$ June respectively at $25 \mathrm{~cm}$ and $15 \mathrm{~cm}$ depths show that the consideration of the temperature-dependence of the moisture content significantly improves the numerical results. Indeed, the predicted local daily variations are in a good agreement with the experimental ones. The local daily variations of relative humidity are strongly related to the local daily variations of temperature. Indeed, relative humidity decreases (respectively increases) with decreasing (respectively increasing) temperature. 
These results are relevant with the temperature effect on sorption process highlighted in $[21,45]$. Moreover, the simulation with hysteresis gives better results than the simulation without.

Fig. 18a and Fig. 18b show the evolution of the relative humidity throughout the year respectively at $25 \mathrm{~cm}$ and $15 \mathrm{~cm}$ depth.
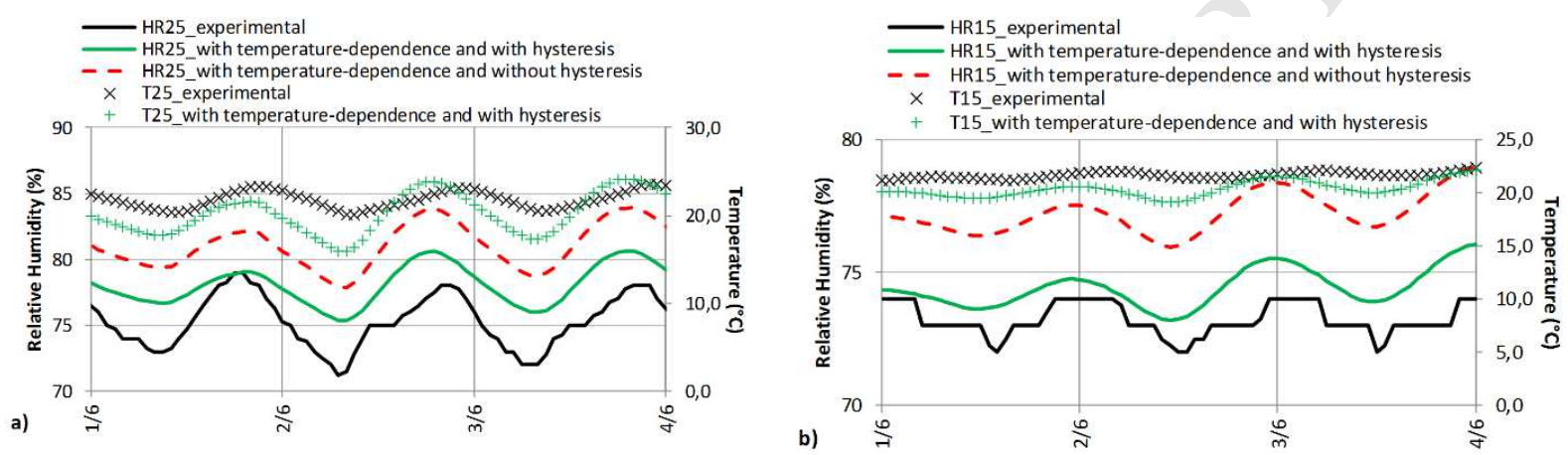

Fig. 17. Evolution of relative humidity and temperature at $25 \mathrm{~cm}$ depth a) and at $15 \mathrm{~cm}$ depth b) from $1^{\text {st }}$ to $4^{\text {th }}$ June 2015 considering the temperature effect on sorption process, with and without hysteresis.
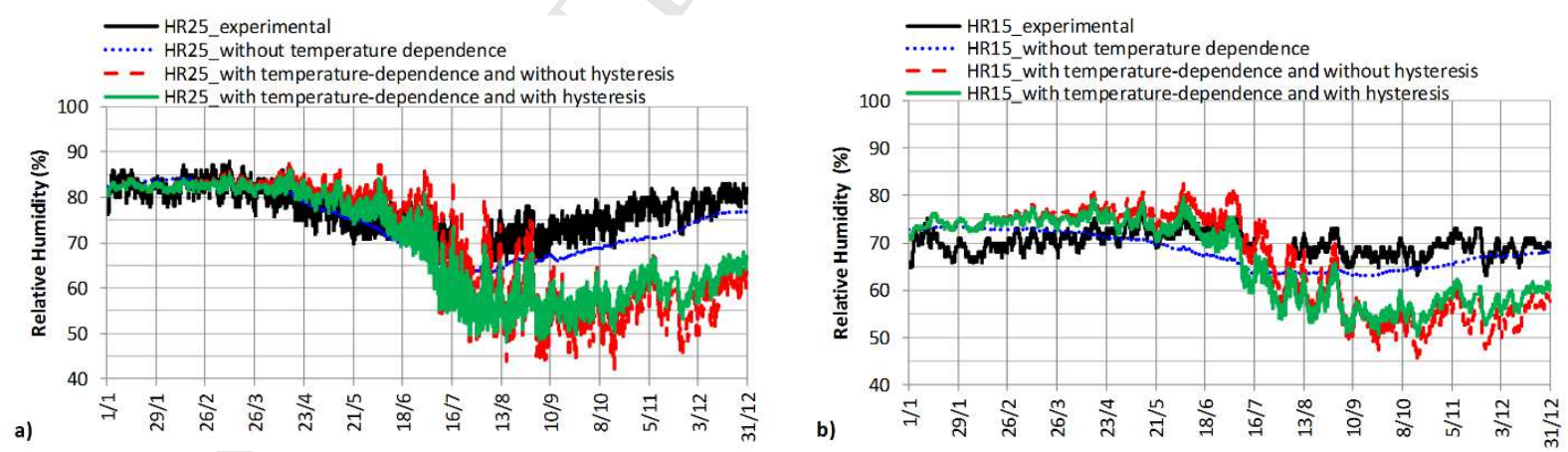

Fig. 18: Evolution of the relative humidity at $25 \mathrm{~cm}$ depth a) and at $15 \mathrm{~cm}$ depth b) from $1^{\text {st }}$ January to $31^{\text {st }}$ December 2015 considering the temperature effect on sorption process, with and without hysteresis.

Whatever the case, the simulated results presented Fig. 18 show that the evolution of the relative humidity is in a good agreement with the experimental results until the end of July. 
During this period, the temperature increases when moisture content highly decreases especially at $25 \mathrm{~cm}$ depth (Fig. 19). Consequently, a slight diminution of relative humidity is observed. In summer, when temperatures are the highest, the moisture content is minimum throughout the wall. Then, from the end of August to the end of the year, moisture content slightly increases with decreasing temperatures. During this period, some discrepancies are observed between numerical and experimental results up to $15 \% \mathrm{RH}$ even though the global trend is respected. This can be explained by the low level of moisture content found with the developed modeling for the highest temperatures reached in the wall (Fig. 19). Indeed, as shown in previous studies [21,38], the consistency of the modeling of the temperaturedependence of moisture content strongly depends on the quality and the quantity of the experimental data collected. In the case of hemp concrete, additional measurements campaigns have to be launched especially at high relative humidities and temperatures [21].

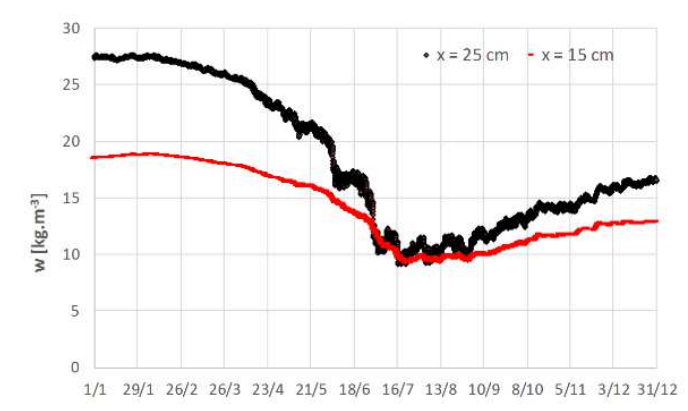

Fig. 19. Evolution of the moisture content at $x=25 \mathrm{~cm}$ depth and $x=15 \mathrm{~cm}$ depth with temperature-dependence and hysteresis consideration.

\section{Conclusion}

In this paper, the hygrothermal performance of a hemp-lime building located in South-West of France is analyzed. The study presents the monitoring results considering the hygrothermal comfort and the hygrothermal behavior of a wall. The evolution of relative humidity and temperature experimentally collected through the wall are also compared with numerical simulations.

Building envelope inspections show a good level of insulation for the $30 \mathrm{~cm}$ thick HLC walls with homogeneous temperature at the exterior surfaces. However, the exposed timber frame 
breaks the continuity of the finishing plaster. The shrinkage of the timber frame creates gaps at the joints between the frame elements and interior finishing of the walls. Due to air leakages at these locations, the result of the envelope airtightness test was poor. This problem can be avoided by applying a continuous plaster over the internal face of the walls. The in situ monitoring of the building shows that HLC helps to maintain hygrothermal conditions at winter and summer comfort levels while outside temperature and relative humidity daily variations are up to $15^{\circ} \mathrm{C}$ and $50 \% \mathrm{RH}$ respectively. In fact, relative humidity of indoor air never falls below $30 \%$ during the heating period, and indoor air temperature never exceeds $27^{\circ} \mathrm{C}$ during summer (even when outdoor air temperature is higher than $35^{\circ} \mathrm{C}$ ). The measurements show also the good thermal inertia of $30 \mathrm{~cm}$ thick HLC wall, which allowed them to dampen the daily temperature and relative humidity variations by $90 \%$ and to delay the effects of peak values up to about 12 hours. It confirms the global idea that bio-based materials are good hygrothermal regulators. However, relative humidity values within the wall are slightly high and need to be further examined in order to evaluate the risk of molds development.

The numerical evolutions of relative humidity and temperature inside the wall give promising results in comparison with the experimental measurements. Nevertheless, despite a more physical representation of the effective hygric behavior of HLC, numerical simulations with hysteresis do not significantly improve the results under the studied hygrothermal conditions. However, the simulations performed show that the consideration of the temperaturedependence of the sorption isotherms gives promising results. The predicted local daily variations of relative humidity through the wall are in a good agreement with the experimental results which show that relative humidity evolutions follow the temperature evolutions.

However, some complementary experimental investigations have to be performed to better identify the influence of temperature on sorption process mechanism for HLC. An uncertainty remains also concerning the effective hygrothermal properties of the coating in lime-sand plaster. In this way, further investigations should be done in the future. 


\section{Acknowledgement}

The authors would like to thank the French Ministry of Sustainable Development for its financial contributions. The authors thank also DB Chanvre Company that provided this construction, and building owners for collaboration.

\section{Bibliography}

[1] S. Pretot, F. Collet, C. Garnier, Life cycle assessment of a hemp concrete wall: Impact of thickness and coating, Build. Environ. 72 (2014) 223-231. doi:10.1016/j.buildenv.2013.11.010.

[2] C. Maalouf, C. Ingrao, F. Scrucca, T. Moussa, A. Bourdot, C. Tricase, A. Presciutti, F. Asdrubali, An energy and carbon footprint assessment upon the usage of hemp-lime concrete and recycled-PET façades for office facilities in France and Italy, J. Clean. Prod. (2016). doi:10.1016/j.jclepro.2016.10.111.

[3] B. Mazhoud, F. Collet, S. Pretot, J. Chamoin, Hygric and thermal properties of hemplime plasters, Build. Environ. 96 (2016) 206-216. doi:10.1016/j.buildenv.2015.11.013.

[4] F. Collet, S. Pretot, Experimental highlight of hygrothermal phenomena in hemp concrete wall, Build. Environ. 82 (2014) 459-466. doi:10.1016/j.buildenv.2014.09.018.

[5] G. Costantine, C. Maalouf, T. Moussa, G. Polidori, Experimental and numerical investigations of thermal performance of a Hemp Lime external building insulation, Build. Environ. 131 (2018) 140-153. doi:10.1016/j.buildenv.2017.12.037.

[6] M.-P. Boutin, C. Flamin, S. Quinton, G. Gosse, Etude des caractéristiques environnementales du chanvre par l'analyse de son cycle de vie, INRA, Lille, France, 2005.

[7] F. Pittau, F. Krause, G. Lumia, G. Habert, Fast-growing bio-based materials as an opportunity for storing carbon in exterior walls, Build. Environ. 129 (2018) 117-129. doi:10.1016/j.buildenv.2017.12.006.

[8] F. Collet, Caractérisation hydrique et thermique de matériaux de génie civil à faibles impacts environnementaux, PhD thesis, INSA de Rennes, 2004.

[9] V. Cerezo, Propriétés mécaniques, thermiques et acoustiques d'un matériau à base de particules végétales: approche expérimentale et modélisation théorique, $\mathrm{PhD}$ thesis, INSA de Lyon, 2005.

[10] D. Samri, Analyse physique et caractérisation hygrothermique des matériaux de construction, PhD thesis, INSA de Lyon, 2008.

[11] J. Chamoin, Optimisation des propriétés (physiques, mécaniques et hydriques) de bétons de chanvre par la maîtrise de la formulation, PhD thesis, INSA de Rennes, 2013.

[12] F. Collet, J. Chamoin, S. Pretot, C. Lanos, Comparison of the hygric behaviour of three hemp concretes, Energy Build. 62 (2013) 294-303. doi:10.1016/j.enbuild.2013.03.010.

[13] S. Elfordy, F. Lucas, F. Tancret, Y. Scudeller, L. Goudet, Mechanical and thermal properties of lime and hemp concrete ("hempcrete") manufactured by a projection process, Constr. Build. Mater. 22 (2008) 2116-2123. doi:10.1016/j.conbuildmat.2007.07.016.

[14] R. Walker, S. Pavia, R. Mitchell, Mechanical properties and durability of hemp-lime concretes, Constr. Build. Mater. $61 \quad$ (2014) 340-348. doi:10.1016/j.conbuildmat.2014.02.065.

[15] F. Collet, S. Pretot, Thermal conductivity of hemp concretes: Variation with formulation, density and water content, Constr. Build. Mater. 65 (2014) 612-619. doi:10.1016/j.conbuildmat.2014.05.039. 
[16] P. de Bruijn, P. Johansson, Moisture fixation and thermal properties of lime-hemp concrete, Constr. Build. Mater. 47 (2013) 1235-1242. doi:10.1016/j.conbuildmat.2013.06.006.

[17] P. Strandberg-de Bruijn, P. Johansson, Moisture transport properties of lime-hemp concrete determined over the complete moisture range, Biosyst. Eng. 122 (2014) 3141. doi:10.1016/j.biosystemseng.2014.03.001.

[18] C.R. Rode, Moisture buffering of building materials., Technical University of Denmark, Denmark, http://orbit.dtu.dk/fedora/objects/orbit:75984/datastreams/file_2415500/content.

[19] F. Collet, S. Pretot, Experimental investigation of moisture buffering capacity of sprayed hemp concrete, Constr. Build. Mater. 36 (2012) 58-65. doi:10.1016/j.conbuildmat.2012.04.139.

[20] Y. Aït Oumeziane, M. Bart, S. Moissette, C. Lanos, Hysteretic Behaviour and Moisture Buffering of Hemp Concrete, Transp. Porous Media. 103 (2014) 515-533. doi:10.1007/s11242-014-0314-7.

[21] Y. Aït Oumeziane, S. Moissette, M. Bart, C. Lanos, Influence of temperature on sorption process in hemp concrete, Constr. Build. Mater. 106 (2016) 600-607. doi:10.1016/j.conbuildmat.2015.12.117.

[22] X. Zhang, W. Zillig, H.M. Künzel, C. Mitterer, X. Zhang, Combined effects of sorption hysteresis and its temperature dependency on wood materials and building enclosurespart II: Hygrothermal modeling, Build. Environ. 106 (2016) 181-195. doi:10.1016/j.buildenv.2016.06.033.

[23] A.D. Tran Le, C. Maalouf, T.H. Mai, E. Wurtz, F. Collet, Transient hygrothermal behaviour of a hemp concrete building envelope, Energy Build. 42 (2010) 1797-1806. doi:10.1016/j.enbuild.2010.05.016.

[24] T. Colinart, P. Glouannec, T. Pierre, P. Chauvelon, A. Magueresse, Experimental Study on the Hygrothermal Behavior of a Coated Sprayed Hemp Concrete Wall, Buildings. 3 (2013) 79-99. doi:10.3390/buildings3010079.

[25] D. Lelievre, T. Colinart, P. Glouannec, Hygrothermal behavior of bio-based building materials including hysteresis effects: Experimental and numerical analyses, Energy Build. 84 (2014) 617-627. doi:10.1016/j.enbuild.2014.09.013.

[26] Y. Aït Oumeziane, S. Moissette, M. Bart, F. Collet, S. Pretot, C. Lanos, Influence of hysteresis on the transient hygrothermal response of a hemp concrete wall, J. Build. Perform. Simul. (2016) 1-16. doi:10.1080/19401493.2016.1216166.

[27] T. Colinart, D. Lelievre, P. Glouannec, Experimental and numerical analysis of the transient hygrothermal behavior of multilayered hemp concrete wall, Energy Build. 112 (2016) 1-11. doi:10.1016/j.enbuild.2015.11.027.

[28] T. Bejat, A. Piot, A. Jay, L. Bessette, Study of Two Hemp Concrete Walls in Real Weather Conditions, Energy Procedia. 78 (2015) 1605-1610. doi:10.1016/j.egypro.2015.11.221.

[29] A. Shea, M. Lawrence, P. Walker, Hygrothermal performance of an experimental hemp-lime building, Constr. Build. Mater. 36 (2012) 270-275. doi:10.1016/j.conbuildmat.2012.04.123.

[30] EN 13829: February 2001 - Thermal performance of buildings - Determination of air permeability of buildings - Fan pressurization method, 2001.

[31] H.M. Künzel, Simultaneous heat and moisture transport in building components. Oneand two-dimensional calculation using simple parameters, Fraunhofer IBP. (1995).

[32] Y. Aït Oumeziane, Evaluation des performances hygrothermiques d'une paroi par simulation numérique : application aux parois en béton de chanvre, $\mathrm{PhD}$ thesis, INSA de Rennes, 2013.

[33] W.K. Lewis, The Evaporation of Liquid into a Gas, Trans. Am. Soc. Mech. Eng. 1849 (1922) 325-340.

[34] C.-E. Hagentoft, A.S. Kalagasidis, B. Adl-Zarrabi, S. Roels, J. Carmeliet, H. Hens, J. Grunewald, M. Funk, R. Becker, D. Shamir, O. Adan, H. Brocken, K. Kumaran, R. Djebbar, Assessment Method of Numerical Prediction Models for Combined Heat, Air 
and

Moisture Transfer in Building Components: Benchmarks for Onedimensional Cases, J. Therm. Envel. Build. Sci. 27 (2004) 327-352. doi:10.1177/1097196304042436.

[35] M.T. Van Genuchten, closed-form equation for predicting the hydraulic conductivity of unsatured soils, Soil Sci. Soc. Am. J. 4 (1980) 892-898.

[36] A. Evrard, Transient hygrothermal behaviour of Lime-Hemp Materials, PhD thesi, Université Catholique de Louvain, 2008.

[37] H.-C. Huang, Y.-C. Tan, C.-W. Liu, C.-H. Chen, A novel hysteresis model in unsaturated soil, Hydrol. Process. 19 (2005) 1653-1665. doi:10.1002/hyp.5594.

[38] S. Poyet, Experimental investigation of the effect of temperature on the first desorption isotherm of concrete, Cem. Concr. Res. 39 (2009) 1052-1059. doi:10.1016/j.cemconres.2009.06.019.

[39] S. Brunauer, The Adsorption of Gases and Vapors. Vol. 1: Physical Adsorption, Princeton University Press, 1945. https://www.abebooks.com/Adsorption-GasesVapors-Vol-Physical-Adsorption/16484029307/bd (accessed October 30, 2017).

[40] T.C. Powers, T.L. Brownyard, Studies of the physical properties of hardened portland cement paste, Research Bulletin 22, Portland Cement Association Bulletin, Chicago, 1948.

[41] F. Richieri, B. Moujalled, T. Salem, F.R. Carrié, Airtightness impact on energy needs and airflow pattern: a numerical evaluation for mechanically ventilated dwellings in France, Int. J. Vent. 15 (2016) 134-150. doi:10.1080/14733315.2016.1203608.

[42] EN 15251: August 2007 - Indoor environmental input parameters for design and assessment of energy performance of buildings addressing indoor air quality, thermal environment, lighting and acoustics, 2007.

[43] ISO 13788: April 2013 - Hygrothermal performance of building components and building elements - Internal surface temperature to avoid critical surface humidity and interstitial condensation - Calculation methods, 2013.

[44] J. Kwiatkowski, M. Woloszyn, J.-J. Roux, Modelling of hysteresis influence on mass transfer in building materials, Build. Environ. 44 (2009) 633-642. doi:10.1016/j.buildenv.2008.05.006.

[45] T. Colinart, P. Glouannec, M. Bendouma, P. Chauvelon, Temperature dependence of sorption isotherm of hygroscopic building materials. Part 2: Influence on hygrothermal behavior of hemp concrete, Energy Build. 152 (2017) 42-51. doi:10.1016/j.enbuild.2017.07.016. 


\section{Experimental and numerical evaluation of the hygrothermal performance of a hemp lime concrete building: a long term case study}

Bassam Moujalleda ${ }^{,}$, Yacine Aït Ouméziane ${ }^{b}$, Sophie Moissettec, Marjorie Bartc, Christophe Lanos ${ }^{c}$, Driss Samrid

a CEREMA, Direction Centre-Est, 46 Rue St Théobald, F-38081 L'Isle d'Abeau, France ${ }^{b}$ FEMTO-ST Institute, Univ. Bourgogne Franche-Comte, CNRS, 2 avenue Jean Moulin, 90000 Belfort, France

c LGCGM EA3913, University of Rennes1, 3 rue du clos Courtel, 35704 RENNES, France ${ }^{d}$ CEREMA, Direction Sud-Ouest, Rue Pierre Ramond, F-33166 Saint-Médard-en-Jalles, France

\section{" Corresponding author:}

E-mail address: bassam.moujalled@cerema.fr

Tel: +33474275155 , Fax: +33474275252

\section{Highlights}

- Hygrothermal performance of a HLC building monitored during 4 years is evaluated.

- Hysteresis and temperature-dependence of moisture content effects are discussed.

- HLC helps to maintain a good hygrothermal comfort level in winter and summer.

- HLC is confirmed to be a good hygrothermal regulator.

- Effect of temperature on sorption enables more realistic results in simulation. 